\title{
Systematic Review for the Medical Applications of Meditation in Randomized Controlled Trials
}

\author{
Do-Young Kim ${ }^{1,+}$, Soo-Hwa Hong ${ }^{1,+}$, Seung-Hyeon Jang ${ }^{1}$, So-Hyeon Park ${ }^{1}{ }^{\mathbb{D}}$, Jung-Hee Noh ${ }^{1}$, Jung-Mi Seok ${ }^{1}$, \\ Hyun-Jeong Jo ${ }^{1}$, Chang-Gue Son ${ }^{2, *}$ and Eun-Jung Lee ${ }^{3, *}$
}

check for

updates

Citation: Kim, D.-Y.; Hong, S.-H.; Jang, S.-H.; Park, S.-H.; Noh, J.-H.; Seok, J.-M.; Jo, H.-J.; Son, C.-G.; Lee, E.-J. Systematic Review for the Medical Applications of Meditation in Randomized Controlled Trials. Int. J. Environ. Res. Public Health 2022, 19, 1244. https://doi.org/10.3390/ ijerph19031244

Academic Editors: Marta Tremolada and Alessio Gori

Received: 10 December 2021

Accepted: 21 January 2022

Published: 22 January 2022

Publisher's Note: MDPI stays neutral with regard to jurisdictional claims in published maps and institutional affiliations.

Copyright: () 2022 by the authors Licensee MDPI, Basel, Switzerland. This article is an open access article distributed under the terms and conditions of the Creative Commons Attribution (CC BY) license (https:// creativecommons.org/licenses/by/ $4.0 /)$.
1 Korean Medical College, Daejeon University, 62, Daehak-ro, Dong-gu, Daejeon 34520, Korea; 95kent@naver.com (D.-Y.K.); 1052akdp@naver.com (S.-H.H.); jshjhi@naver.com (S.-H.J.); jenpsh@gmail.com (S.-H.P.); dhy03065@naver.com (J.-H.N.); cococ000@naver.com (J.-M.S.); perarduaadastra9@naver.com (H.-J.J.)

2 Department of Liver and Immunology Research Center, Daejeon Oriental Hospital of Daejeon University, 75, Daedeok-daero 176, Seo-gu, Daejeon 35235, Korea

3 Department of Korean Rehabilitation Medicine, Daejeon Oriental Hospital of Daejeon University, 75, Daedeok-daero 176, Seo-gu, Daejeon 35235, Korea

* Correspondence: ckson@dju.ac.kr (C.-G.S.); jungkahn@dju.kr (E.-J.L.)

+ These authors contributed equally to this work.
Abstract: Background: Meditation has been increasingly adapted for healthy populations and participants with diseases. Its beneficial effects are still challenging to determine due to the heterogeneity and methodological obstacles regarding medical applications. This study aimed to integrate the features of therapeutic meditation in randomized controlled trials (RCTs). Methods: We conducted a systematic review of RCTs with meditation for populations with diseases using the PubMed database through June 2021. We analyzed the characteristics of the diseases/disorders, participants, measurements, and their overall benefits. Results: Among a total of 4855 references, 104 RCTs were determined and mainly applied mindfulness-based (51 RCTs), yoga-based (32 RCTs), and transcendental meditation (14 RCTs) to 10,139 patient-participants. These RCTs were conducted for participants with a total of 45 kinds of disorders; the most frequent being cancer, followed by musculoskeletal and connective tissue diseases and affective mood disorder. Seven symptoms or signs were frequently assessed: depressive mood, feeling anxious, quality of life, stress, sleep, pain, and fatigue. The RCTs showed a higher ratio of positive outcomes for sleep $(73.9 \%)$ and fatigue $(68.4 \%)$. Conclusions: This systematic review produced the comprehensive features of RCTs for therapeutic meditation. These results will help physicians and researchers further study clinical adaptations in the future as reference data.

Keywords: meditation; RCT; review; depression; sleep; fatigue

\section{Introduction}

Meditation is a mental practice aiming to improve the psychological capacity of selfregulation regarding attention, awareness, and emotion [1]. Its implementation has been described not only in religious and cultural beliefs but also in health promotion as itself or as a component of mind-body practices such as yoga, qigong, tai chi, and mindfulnessbased interventions (MBIs) [2]. The US National Center for Complementary and Integrative Health $(\mathrm{NCCIH})$ reported the health benefits of meditation, including the regulation of blood pressure and blood glucose and stress reduction for healthy participants [3]. From 2012 to 2017 , the use of meditation more than tripled from $4.1 \%$ to $14.2 \%$ in the general US adult population [4].

Additionally, meditation for patients in clinics against diverse disease conditions, such as complementary and alternative medicine (CAM), has been demanded [5]. Therapeutic meditation techniques include MBIs, yoga-based programs, and transcendental meditation 
(TM) [2]. Mindfulness-based stress reduction (MBSR) and mindfulness-based cognitive therapy (MBCT), which are representative MBIs, have presented psychological benefits for patients with depression and cancers [6,7]. Yogic meditation and TM also produce preventive benefits regarding risk factors for cardiovascular diseases and affective disorders by regulating brain activity and the autonomic nervous system $[8,9]$.

However, it is difficult to objectify the effect of meditation because of its methodological obstacles, such as diverse task forms, a wide range of traditional roots, and the proficiency of practicians [10]. The NCCIH pointed out that scientific research on meditation practices has a heterogeneous theoretical perspective and poor study design quality [3]. Most of the 400 clinical studies for meditation conducted before 2005 were considered to be poorly designed [11], while more recent meditation-derived clinical studies include many well-designed trials [12,13]. Physicians need to consider the characteristics of meditative intervention and its expected effect for application in their treatment plans. To date, no systematic analysis showing the current status of clinical applications for patients exists.

To facilitate these works, this study comprehensively reviewed the features of randomized controlled trials (RCTs) with meditative interventions designed for patients to date regarding patients, interventions, controls, measurements, and overall results.

\section{Methods}

\subsection{Database and Searching Strategy}

The literature survey of this review was conducted in accordance with the Preferred Reporting Items for Systematic Reviews and Meta-Analysis (PRISMA) guidelines [14] using the PubMed electronic database through 10 June 2021. The search term used was 'meditation [Title/Abstract]' with excluding filters [Systematic review, Review, Meta-analysis]. The literature survey was conducted by 6 individual reviewers, and the third one checked the process.

\subsection{Eligibility Criteria}

The literature screening process of this study used the following inclusion criteria: (1) studies that were RCTs or randomized controlled crossover trials; (2) the study participants were patients with diseases; and (3) studies that evaluated the therapeutic efficacy of meditation. The exclusion criteria were as follows: (1) articles with no full text; (2) pilot RCTs or post-analysis studies; (3) studies with a Jadad score less than 3 points; and (4) studies with results published in languages other than English.

\subsection{Data Extraction and Quality Assessment}

Data extraction dealt with the number of participants, mean age, subjects' diseases, intervention category, treatment period, control, and outcome measurements. We also obtained the result data of the original article with a statistical analysis of the treatment effect compared to the control.

To assess the quality of the RCTs, the Jadad scale was used [15]. The Jadad scale is a five-point checklist scale that allocates points for descriptions of randomization, doubleblinding, withdrawals, and drop-outs. Trials with $\geq 3$ points were considered high quality and were included in this study.

\subsection{Categorization of Meditation}

We categorized meditative interventions into 3 groups (Mindfulness- and yoga-based meditation and TM). Mindfulness-based or yoga-based meditation included interventions with the terms "mindfulness" or "yoga" used in each original article. The TM group included TM, mantras, and spiritual meditation.

\subsection{Judgment of the Statistical Efficiency of the Intervention}

We judged the benefit of intervention with statistical significance based on the data presentations of the original articles. In general, 'statistical significance' meant that the 
intervention showed statistically significant improvement (intervention vs. control, $p<$ 0.05 or Cohen's $\mathrm{d}>0.5$ ) according to the outcome measurement at the planned time point or the closest time to the end of the treatment period. We defined 'benefit with statistical significance' for the following cases: (1) One or more of the outcomes regarding target symptoms or signs were statistically significant, or (2) statistical significance was observed only at the planned time point or the closest point to the period after treatment, unless any description was noted.

\subsection{Data Analysis}

This systematic review did not need to apply statistical analysis. Regarding the number of participants, age, and treatment periods in the demographic features, the data are presented as the mean and standard deviation (SD) computed by Microsoft Excel software.

\section{Results}

\subsection{General Characteristics of the RCTs}

A total of 4855 initial references were identified from PubMed, and 104 articles met the inclusion criteria of this review (Figure 1). In the 104 RCTs, 10,139 (3117 males and 7022 females) patients participated (mean age: $47.6 \pm 13.1$ years), and the mean treatment period was $10.3 \pm 9.1$ weeks (Table 1 ). The controls included usual therapy (29 RCTs), waitlist (16 RCTs), education (15 RCTs), and relaxation (11 RCTs) (Tables 2 and 3). The RCTs were predominantly conducted in the USA $(n=41)$, followed by India $(n=15)$ and Germany $(n=9)$ (data not shown).

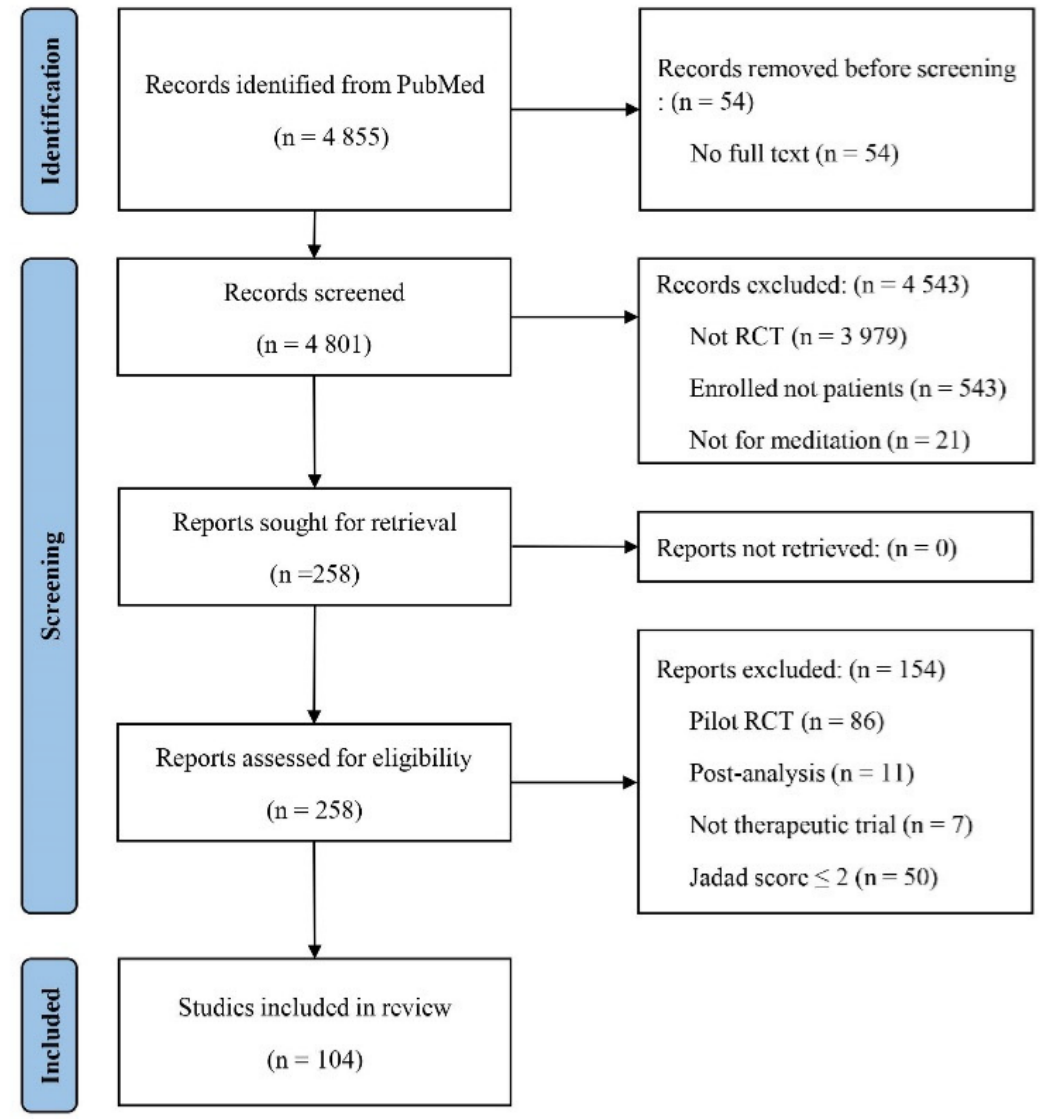

Figure 1. Flow chart of the study. 
Table 1. Study characteristics.

\begin{tabular}{|c|c|}
\hline Items & Count \\
\hline N. of RCT & 104 \\
\hline N. of participants (female) & $10,139(7022)$ \\
\hline Mean N. of participant (the number \pm SD) & $97.3 \pm 71.4$ \\
\hline Mean age $(\text { year } \pm S D)^{A}$ & $47.6 \pm 13.1$ \\
\hline Mean treatment period (week \pm SD) & $10.3 \pm 9.1$ \\
\hline Disorders of the participants (N. of RCT, \%) & $104(100)$ \\
\hline Cancer & $16(15.4)$ \\
\hline Diseases of the musculoskeletal and connective tissues & $14(13.5)$ \\
\hline Affective mood disorder & $13(12.5)$ \\
\hline Disease of the nervous system & $9(8.7)$ \\
\hline Disease of the circulatory system & $7(6.7)$ \\
\hline Gynecological disorder & $7(6.7)$ \\
\hline Post-traumatic stress disorder (PTSD) & $7(6.7)$ \\
\hline Metabolic disorder & $6(5.8)$ \\
\hline Disease of otorhinolaryngology & $5(4.8)$ \\
\hline Others & $20(19.2)$ \\
\hline \multicolumn{2}{|l|}{ Type of meditation ${ }^{B}$ (N. of RCTs, \%) } \\
\hline Mindfulness-based meditation & $51(49.0)$ \\
\hline Yoga-based meditation & $32(30.8)$ \\
\hline Transcendental meditation & $14(13.5)$ \\
\hline Others & $11(10.6)$ \\
\hline \multicolumn{2}{|l|}{ Main clinical outcomes B, C (N. of RCTs, \%) } \\
\hline Mean N. of measurements per RCT (the number \pm SD) & $3.9 \pm 2.5$ \\
\hline Depressive mood & $56(53.8)$ \\
\hline Feeling anxious & $40(38.5)$ \\
\hline Quality of life (QoL) & $32(30.8)$ \\
\hline Stress & $31(29.8)$ \\
\hline Sleep & $23(22.1)$ \\
\hline Pain & $22(21.2)$ \\
\hline Fatigue & $19(18.3)$ \\
\hline
\end{tabular}

\subsection{Diseases of the Participants and Types of Meditation in the RCTs}

Among a total of 104 RCTs, 73 trials (70.2\%) were performed for participants with physical diseases, and 31 (29.8\%) were performed for participants with mental disorders (Tables 2 and 3). The physical diseases included cancer (16 RCTs), followed by musculoskeletal and connective tissue (14 RCTs), nervous system (9 RCTs), circulatory system and gynecological diseases (7 RCTs each). On the other hand, affective disorder (13 RCTs) and post-traumatic stress disorder (PTSD, 7 RCTs) were the most frequent mental diseases in the subjects (Table 1 ). 
Table 2. Summary of the RCTs for participants with physical disorders.

\begin{tabular}{|c|c|c|c|c|c|}
\hline \multirow{2}{*}{ Disorder [Reference] } & \multirow{2}{*}{ Kind of Meditation (Category *) } & \multirow{2}{*}{$\begin{array}{c}\text { N. of Participants \# (N. of Arms, } \\
\text { Controls) }\end{array}$} & \multirow{2}{*}{ Period (Weeks) } & \multicolumn{2}{|c|}{ Clinical Finding (Statistical) } \\
\hline & & & & Significant & Not Significant \\
\hline \multicolumn{6}{|c|}{ Cancer } \\
\hline Breast cancer [16] & Kirtan Kriya $(Y+T)$ & 31 (2, music listening) & 8 & $\begin{array}{l}\text { depressive mood, fatigue, cognitive } \\
\text { functions } \mathrm{A}\end{array}$ & $\begin{array}{l}\text { feeling anxious, stress, } \\
\text { self-efficacy }\end{array}$ \\
\hline Breast cancer [17] & $\mathrm{MM}(\mathrm{M})$ & $\begin{array}{c}92 \text { ( } 3 \text {, muscle relaxation, } \\
\text { education) }\end{array}$ & 12 & fatigue $^{\mathrm{A}}$ & QoL \\
\hline Breast cancer [18] & Self-care toolkit (other) & 100 (2, usual care) & 2 & pain & $\begin{array}{c}\text { depressive mood, feeling anxious } \\
\text { A, sleep, fatigue, social role, } \\
\text { physical functions, nausea }\end{array}$ \\
\hline Breast cancer [19] & Tai chi (other) & $90(2, \mathrm{CBT})$ & 12 & depressive mood, sleep ${ }^{\mathrm{A}}$, fatigue & - \\
\hline Breast cancer [20] & Yoga $(Y)$ & $69(2$, counseling $)$ & 24 & $\begin{array}{l}\text { depressive mood, feeling anxious, } \\
\text { cancer symptoms }\end{array}$ & - \\
\hline Breast cancer [21] & Hatha yoga $(\mathrm{Y})$ & 40 (2, waitlist) & 12 & QoL, fatigue, menopausal symptoms & depressive mood, feeling anxious \\
\hline Breast cancer [22] & YOCAS (Y) & 167 (2, waitlist) & 4 & fatigue & - \\
\hline Breast cancer [23] & Qigong + Tai chi (other) & 87 (2, sham qigong) & 12 & fatigue $^{\mathrm{A}}$ & depressive mood, sleep \\
\hline Breast cancer [24] & Mindful awareness practices (M) & 71 (2, usual care) & 6 & $\begin{array}{c}\text { stress }^{A} \text {, sleep, fatigue, hot flashes, } \\
\text { affect }\end{array}$ & $\begin{array}{l}\text { depressive mood }{ }^{\mathrm{A}} \text {, pain, fear, } \\
\text { intrusive thoughts }\end{array}$ \\
\hline Breast cancer [25] & $\begin{array}{l}\text { Mindfulness-based cancer } \\
\text { recovery }(\mathrm{M})\end{array}$ & $\begin{array}{l}271 \text { (3, supportive therapy, stress } \\
\text { management) }\end{array}$ & 8 & stress, $\operatorname{mood}{ }^{\mathrm{A}}$ & $\begin{array}{l}\text { health-related functions, social } \\
\text { support }\end{array}$ \\
\hline Cancer [26] & Yoga $(Y)$ & $410(2$, usual care $)$ & 4 & sleep $^{A}$ & 11 \\
\hline Breast cancer [27] & MBSR (M) & $336(2$, usual care $)$ & 8 & - & sleep ${ }^{A}$ \\
\hline Breast cancer [28] & Danhak (other) & $102(2$, usual care $)$ & 6 & feeling anxious ${ }^{\mathrm{A}}$, fatigue, $\mathrm{QoL}$ & $\begin{array}{c}\text { depressive mood }{ }^{\mathrm{A}} \text {, dyspnea } \\
\text { depressive mood, feeling anxious, }\end{array}$ \\
\hline Cancer [29] & $\operatorname{MBSR}(\mathrm{M})$ & 71 (2, waitlist) & 24 & - & $\begin{array}{l}\text { stress, intrusive thoughts, } \\
\text { avoidance, hyperarousal, } \\
\text { positive thinking, self-efficacy }\end{array}$ \\
\hline Breast cancer [30] & $\mathrm{TM}(\mathrm{T})$ & $130(2$, usual care $)$ & 72 & $\begin{array}{c}\text { QoL }{ }^{\mathrm{A}} \text {, spiritual well-being, mental } \\
\text { health }\end{array}$ & vitality \\
\hline Cancer [31] & $\operatorname{MBSR}(\mathrm{M})$ & 90 (2, waitlist) & 7 & $\begin{array}{l}\text { depressive mood, feeling anxious, } \\
\text { stress, anger, vigor, confusion, mood, } \\
\text { habitual patterns, irritability }\end{array}$ & fatigue, peripheral symptoms \\
\hline
\end{tabular}


Table 2. Cont.

\begin{tabular}{|c|c|c|c|c|c|}
\hline \multirow{2}{*}{ Disorder [Reference] } & \multirow{2}{*}{ Kind of Meditation (Category *) } & \multirow{2}{*}{$\begin{array}{l}\text { N. of Participants }{ }^{\#} \text { (N. of Arms, } \\
\text { Controls) }\end{array}$} & \multirow{2}{*}{ Period (Weeks) } & \multicolumn{2}{|c|}{ Clinical Finding (Statistical) } \\
\hline & & & & Significant & Not Significant \\
\hline \multicolumn{6}{|c|}{ Diseases of the musculoskeletal system and connective tissues } \\
\hline $\begin{array}{c}\text { Rheumatoid arthritis } \\
\text { [32] }\end{array}$ & $\begin{array}{l}\text { Yoga-based mind-body } \\
\text { intervention }(\mathrm{Y})\end{array}$ & $72(2$, usual care $)$ & 8 & $\begin{array}{c}\text { depressive mood, inflammatory } \\
\text { markers A }\end{array}$ & - \\
\hline Knee osteoarthritis [33] & $\operatorname{Mantra}(\mathrm{Y}+\mathrm{T})$ & 22 (2, music listening) & 8 & sleep, mood & $\begin{array}{c}\text { QoL, stress, pain }{ }^{\mathrm{A}} \text {, osteoarthritis } \\
\text { symptoms } \mathrm{A}\end{array}$ \\
\hline Fibromyalgia [34] & $\begin{array}{l}\text { Meditation awareness training } \\
(\mathrm{M})\end{array}$ & $148(2, \mathrm{CBT})$ & 8 & $\begin{array}{c}\text { depressive mood }{ }^{\mathrm{A}} \text {, feeling anxious } \\
\mathrm{A} \text {, stress } \mathrm{A} \text {, sleep } \mathrm{A} \text {, pain } \mathrm{A}^{\prime} \\
\text { fibromyalgia symptoms }{ }^{\prime}, \\
\text { nonattachment, civic engagement }\end{array}$ & 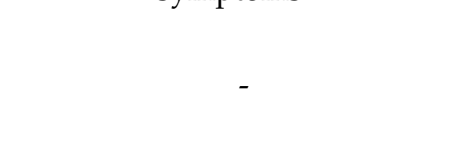 \\
\hline $\begin{array}{l}\text { Chronic low back pain } \\
\text { [35] }\end{array}$ & $\operatorname{MBSR}(\mathrm{M})$ & 341 (3, CBT, usual care) & 8 & $\begin{array}{c}\text { pain }{ }^{\mathrm{A}}, \text { disability }{ }^{\mathrm{A}} \text {, global } \\
\text { impression }\end{array}$ & $\begin{array}{c}\text { depressive mood, feeling } \\
\text { anxious, QoL }\end{array}$ \\
\hline $\begin{array}{l}\text { Chronic low back pain } \\
\text { [36] }\end{array}$ & Jyoti meditation $(\mathrm{Y})$ & $68(2$, exercise $)$ & 8 & stress & $\begin{array}{l}\text { depressive mood, feeling } \\
\text { anxious, QoL, pain A , disability }\end{array}$ \\
\hline Fibromyalgia [37] & $\operatorname{MBSR}(\mathrm{M})$ & 91 (2, usual care) & 8 & $\begin{array}{l}\text { stress, sleep, fatigue, fibromyalgia } \\
\text { symptoms }\end{array}$ & $\begin{array}{l}\text { physical function, salivary } \\
\text { cortisol }\end{array}$ \\
\hline Chronic neck pain [38] & Jyoti meditation $(\mathrm{Y})$ & 89 ( 2 , exercise $)$ & 8 & pain ${ }^{A}$ & $\begin{array}{l}\text { depressive mood, feeling } \\
\text { anxious, QoL, stress }\end{array}$ \\
\hline Knee osteoarthritis [40] & Yoga $(Y)$ & 250 (2, physiotherapy exercise) & 14 & QoL & - \\
\hline Chronic pain [41] & $\operatorname{MBSR}(\mathrm{M})$ & $\begin{array}{l}99 \text { (2, multidisciplinary pain } \\
\text { intervention) }\end{array}$ & 8 & vigorous activity & $\begin{array}{l}\text { depressive mood, feeling } \\
\text { anxious, QoL, pain } \mathrm{A} \text {, fatigue, } \\
\text { anger, confusion }\end{array}$ \\
\hline Fibromyalgia [42] & $\operatorname{MBSR}(\mathrm{M})$ & $\begin{array}{c}168 \text { (3, nonspecific MBSR, } \\
\text { waitlist) }\end{array}$ & 8 & - & $\begin{array}{l}\text { depressive mood, feeling anxious, } \\
\text { QoL }{ }^{A} \text {, sleep, pain, mindfulness }\end{array}$ \\
\hline $\begin{array}{l}\text { Chronic low back pain } \\
\text { [43] }\end{array}$ & Yoga $(Y)$ & 80 ( 2 , exercise $)$ & 1 & pain, flexibility & \\
\hline $\begin{array}{l}\text { Rheumatoid arthritis } \\
\text { [44] }\end{array}$ & $\mathrm{MM}(\mathrm{M})$ & 106 (3, CBT, education) & 8 & - & $\begin{array}{c}\text { depressive mood }{ }^{\mathrm{A}} \text {, pain }{ }^{\mathrm{A}} \text {, affect } \\
\mathrm{A} \text {, swelling, tenderness }\end{array}$ \\
\hline $\begin{array}{l}\text { Rheumatoid arthritis } \\
\text { [45] }\end{array}$ & $\operatorname{MBSR}(\mathrm{M})$ & 63 (2, waitlist) & 8 & & $\begin{array}{l}\text { depressive mood } \mathrm{A} \text {, rheumatoid } \\
\text { arthritis symptoms } \mathrm{A} \text {, mental } \\
\text { well-being, mindfulness }\end{array}$ \\
\hline
\end{tabular}


Table 2. Cont.

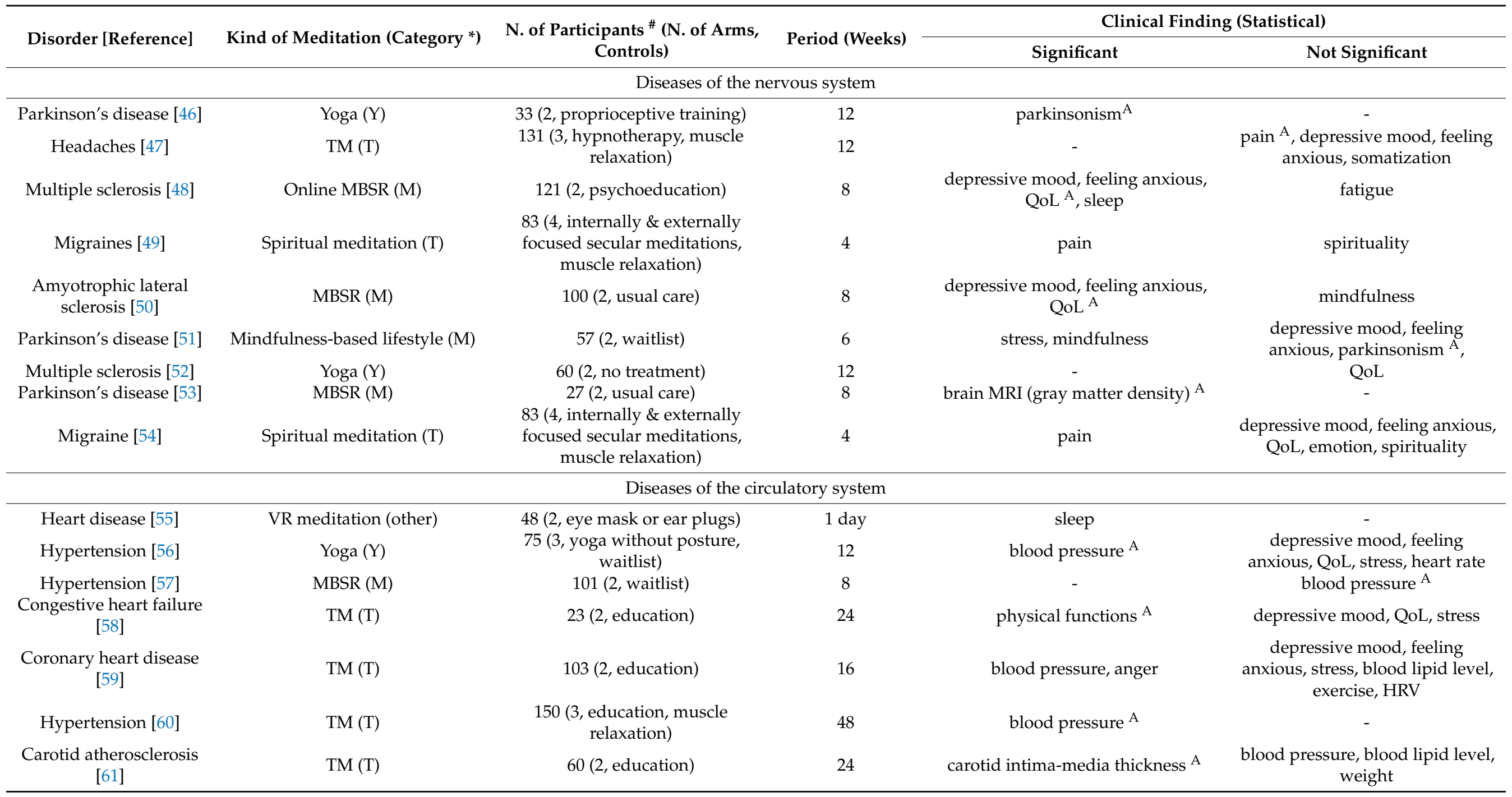


Table 2. Cont.

\begin{tabular}{|c|c|c|c|c|c|}
\hline \multirow{2}{*}{ Disorder [Reference] } & \multirow{2}{*}{ Kind of Meditation (Category *) } & \multirow{2}{*}{$\begin{array}{c}\text { N. of Participants }{ }^{\#} \text { (N. of Arms, } \\
\text { Controls) }\end{array}$} & \multirow{2}{*}{ Period (Weeks) } & \multicolumn{2}{|c|}{ Clinical Finding (Statistical) } \\
\hline & & & & Significant & Not Significant \\
\hline \multicolumn{6}{|c|}{ Gynecological disorders } \\
\hline $\begin{array}{c}\text { Gynecological disease } \\
{[62]}\end{array}$ & Mobile app Calm (M) & 101 (2, usual care) & 4 & $\begin{array}{c}\text { depressive mood, feeling anxious, } \\
\text { stress } \mathrm{A} \text {, sleep }\end{array}$ & - \\
\hline Chronic pelvic pain [63] & Mobile app-based MM (M) & $\begin{array}{c}90(3, \text { muscle relaxation, usual } \\
\text { care })\end{array}$ & 8 & - & pain $^{A}$ \\
\hline Dysmenorrhea [64] & Yoga $(Y)$ & $36(2$, no treatment $)$ & 12 & stress, pain & - \\
\hline $\begin{array}{c}\text { Menopausal disorder } \\
{[66]}\end{array}$ & Yoga $(Y)$ & $180(2$, no treatment $)$ & 12 & menopausal symptoms ${ }^{A}$ & - \\
\hline $\begin{array}{c}\text { Menopausal disorder } \\
{[67]}\end{array}$ & Yoga $(Y)$ & 120 (2, exercise) & 8 & $\begin{array}{l}\text { stress, vasomotor symptoms, } \\
\text { personality }\end{array}$ & $\begin{array}{c}\text { psychological symptoms, somatic } \\
\text { symptoms }\end{array}$ \\
\hline $\begin{array}{c}\text { Menopausal disorder } \\
{[68]}\end{array}$ & Yoga $(Y)$ & 108 (2, exercise) & 8 & cognitive function ${ }^{A}$ & vasomotor symptoms A \\
\hline \multicolumn{6}{|c|}{ Metabolic disorders } \\
\hline DM type 2 [69] & $\operatorname{MBSR}(\mathrm{M})$ & $\begin{array}{c}69 \text { (3, muscle relaxation, } \\
\text { education) }\end{array}$ & 12 & - & QoL, pain ${ }^{A}$, fatigue \\
\hline $\begin{array}{l}\text { DM type } 2+ \\
\text { amputation [70] }\end{array}$ & $\mathrm{TM}(\mathrm{T})$ & 54 (2, diabetic care training) & 4 & amputee body image ${ }^{\mathrm{A}}$ & - \\
\hline Obesity [71] & $\operatorname{MBSR}(\mathrm{M})$ & 194 (2, muscle relaxation) & 22 & - & sleep ${ }^{A}$ \\
\hline DM type $2[72]$ & $\operatorname{MBSR}(\mathrm{M})$ & 56 (3, walking, education) & 8 & inflammatory response & stress $^{\mathrm{A}}$, blood glucose ${ }^{\mathrm{A}}$ \\
\hline DM type $2[73]$ & Mindful eating intervention (M) & $52(2$, self-management $)$ & 12 & - & $\begin{array}{l}\text { depressive mood, feeling anxious, } \\
\text { DM symptoms } \mathrm{A} \text {, mindfulness } \\
\text { depressive mood, feeling }\end{array}$ \\
\hline $\begin{array}{c}\text { Metabolic syndrome } \\
{[74]}\end{array}$ & $\begin{array}{l}\text { Consciously resting meditation } \\
\qquad(\mathrm{Y}+\mathrm{T})\end{array}$ & 68 ( 2 , education) & 12 & stress, vascular functions ${ }^{A}$ & $\begin{array}{c}\text { anxious, hostility, anger, physical } \\
\text { activity, metabolic \& } \\
\text { inflammatory markers }\end{array}$ \\
\hline \multicolumn{6}{|c|}{ Diseases of otorhinolaryngology } \\
\hline Glaucoma [75] & $\mathrm{MM}(\mathrm{M})$ & $60(2$, medication $)$ & 3 & QoL, IOPA & - \\
\hline Glaucoma [76] & Breathing meditation (other) & 60 (2, usual care) & 6 & - & QoL, IOPA , blood markers \\
\hline Glaucoma [77] & $\operatorname{MBSR}(\mathrm{M})$ & 90 (2, usual care) & 3 & QoL, IOP ${ }^{\mathrm{A}}$, blood markers & visual field \\
\hline
\end{tabular}


Table 2. Cont.

\begin{tabular}{|c|c|c|c|c|c|}
\hline \multirow{2}{*}{ Disorder [Reference] } & \multirow{2}{*}{ Kind of Meditation (Category *) } & \multirow{2}{*}{$\begin{array}{c}\text { N. of Participants \# (N. of Arms, } \\
\text { Controls) }\end{array}$} & \multirow{2}{*}{ Period (Weeks) } & \multicolumn{2}{|c|}{ Clinical Finding (Statistical) } \\
\hline & & & & Significant & Not Significant \\
\hline Tinnitus [78] & $\mathrm{MM}(\mathrm{M})$ & $61(2$, relaxation $)$ & 15 & tinnitus symptoms ${ }^{A}$ & $\begin{array}{l}\text { depressive mood, feeling } \\
\text { anxious, body temperature }\end{array}$ \\
\hline Tinnitus [79] & $\operatorname{MBCT}(\mathrm{M})$ & 75 (2, relaxation) & 8 & $\begin{array}{c}\text { tinnitus symptoms }{ }^{\mathrm{A}} \text {, attention } \\
\text { awareness }\end{array}$ & $\begin{array}{l}\text { depressive mood, feeling anxious, } \\
\text { stress A, social adjustment }\end{array}$ \\
\hline \multicolumn{6}{|c|}{ Diseases of the digestive system } \\
\hline $\begin{array}{l}\text { Foregut surgery [80] } \\
\text { Functional }\end{array}$ & VR meditation (other) & 52 (2, usual care) & 1 day & - & feeling anxious, pain, nausea \\
\hline $\begin{array}{l}\text { gastrointestinal } \\
\text { disorders [81] }\end{array}$ & Yoga $(Y)$ & 69 (2, usual care) & 10 & - & pain ${ }^{\mathrm{A}}$, well-being \\
\hline $\begin{array}{l}\text { Inflammatory bowel } \\
\text { disease [82] }\end{array}$ & Mindfulness-based therapy (M) & 66 (2, usual care) & 16 & - & $\begin{array}{c}\text { stress, inflammatory bowel } \\
\text { disease symptoms A, positive } \\
\text { thinking, avoidance, seeking } \\
\text { advice, self-blame }\end{array}$ \\
\hline \multicolumn{6}{|c|}{ Others } \\
\hline COPD [83] & Breathing-based walking (other) & 78 (2, usual care) & 8 & $\begin{array}{l}\text { depressive mood, feeling anxious, } \\
\text { COPD symptoms, }\end{array}$ & - \\
\hline HIV [84] & Yoga $(Y)$ & 60 (2, waitlist) & 8 & $\begin{array}{l}\text { depressive mood, feeling anxious, } \\
\text { QoL }{ }^{\mathrm{A}} \text {, fatigue, well-being }\end{array}$ & - \\
\hline Periodontitis [85] & Yoga $(Y)$ & 80 (2, usual care) & 12 & stress, periodontitis symptoms & - \\
\hline Renal disease [86] & Telephone MBSR (M) & 55 (2, telephone support) & 8 & depressive mood & $\begin{array}{c}\text { feeling anxious }{ }^{\mathrm{A}}, \mathrm{QoL} \text {, sleep, } \\
\text { pain, fatigue }\end{array}$ \\
\hline HIV [87] & Yoga $(\mathrm{Y})$ & 47 ( 2, usual care) & 12 & $\begin{array}{l}\text { stress, positive affect }{ }^{\mathrm{A}} \text {, mental } \\
\text { well-being } \mathrm{A} \text {, general health, social } \\
\text { functions, cognitive functions }\end{array}$ & \\
\hline Asthma [88] & Sahaja yoga $(\mathrm{Y})$ & $\begin{array}{c}47 \text { (2, relaxation + group } \\
\text { discussion + CBT-like exercise })\end{array}$ & 16 & $\begin{array}{c}\text { feeling anxious, fatigue, asthma } \\
\text { symptoms A }\end{array}$ & $\begin{array}{l}\text { depressive mood, } \mathrm{QoL}^{\mathrm{A}} \text {, anger, } \\
\text { vigor, confusion }\end{array}$ \\
\hline
\end{tabular}


Table 3. Summary of the RCTs for participants with mental disorders.

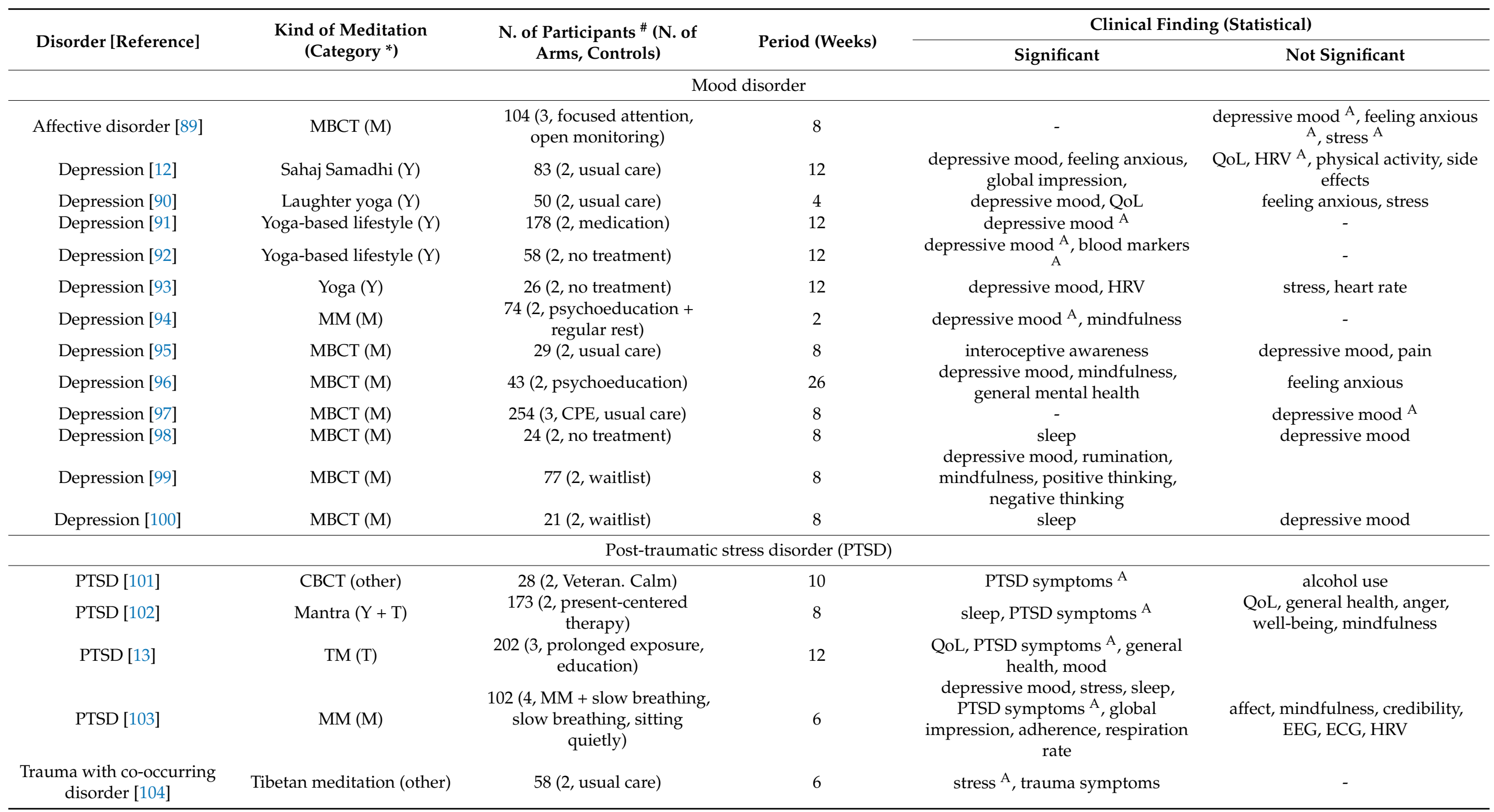


Table 3. Cont.

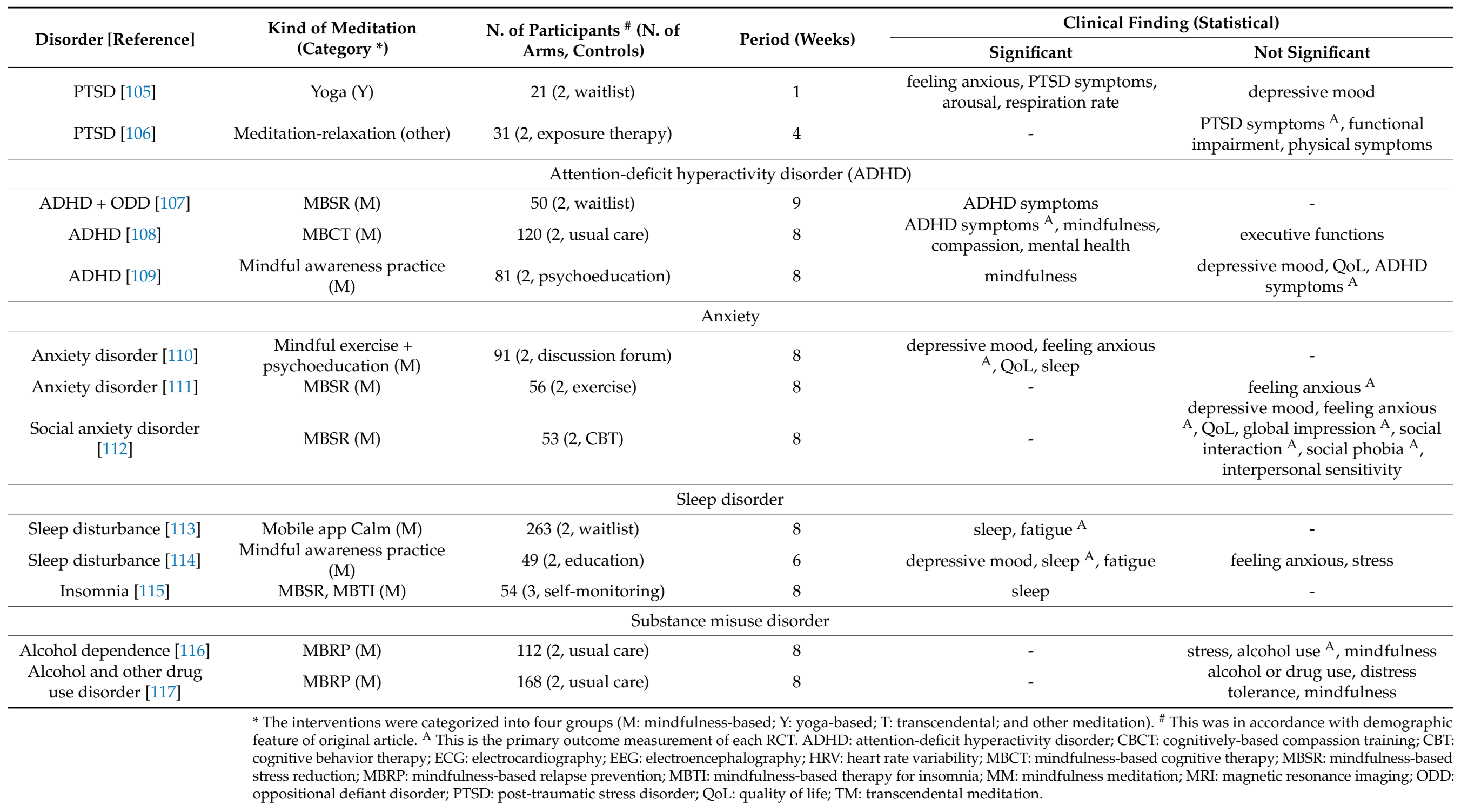


In terms of the interventions used in the RCTs, 34 kinds of meditations were employed. Ninety-three trials (89.4\%, out of 104 total) employed at least one of the three major meditative interventions: mindfulness-based (51 RCTs), yoga-based (32 RCTs), or TM (14 RCTs) (Table 1). Further detailed information for the diseases/disorders and types of meditations is shown in Table 2.

\subsection{Target Measurements in the RCTs}

From a total of 104 RCTs, the mean number of assessed outcomes per RCT was $3.9 \pm 2.5$, which presented 105 kinds of outcomes (Table 1$)$. A total of 76 RCTs (73.1\%) reported primary outcome measurements, which produced 99 primary outcomes for 41 kinds of measurements. Ten kinds of measurements were reported in at least three RCTs, including pain (11 RCTs), depressive mood (10 RCTs), feeling anxious (8 RCTs), quality of life (QoL, 7 RCTs), stress (7 RCTs), sleep (6 RCTs), PTSD symptoms (5 RCTs), blood pressure, intraocular pressure (IOP), and fatigue (3 RCTs each) (Figure 2).

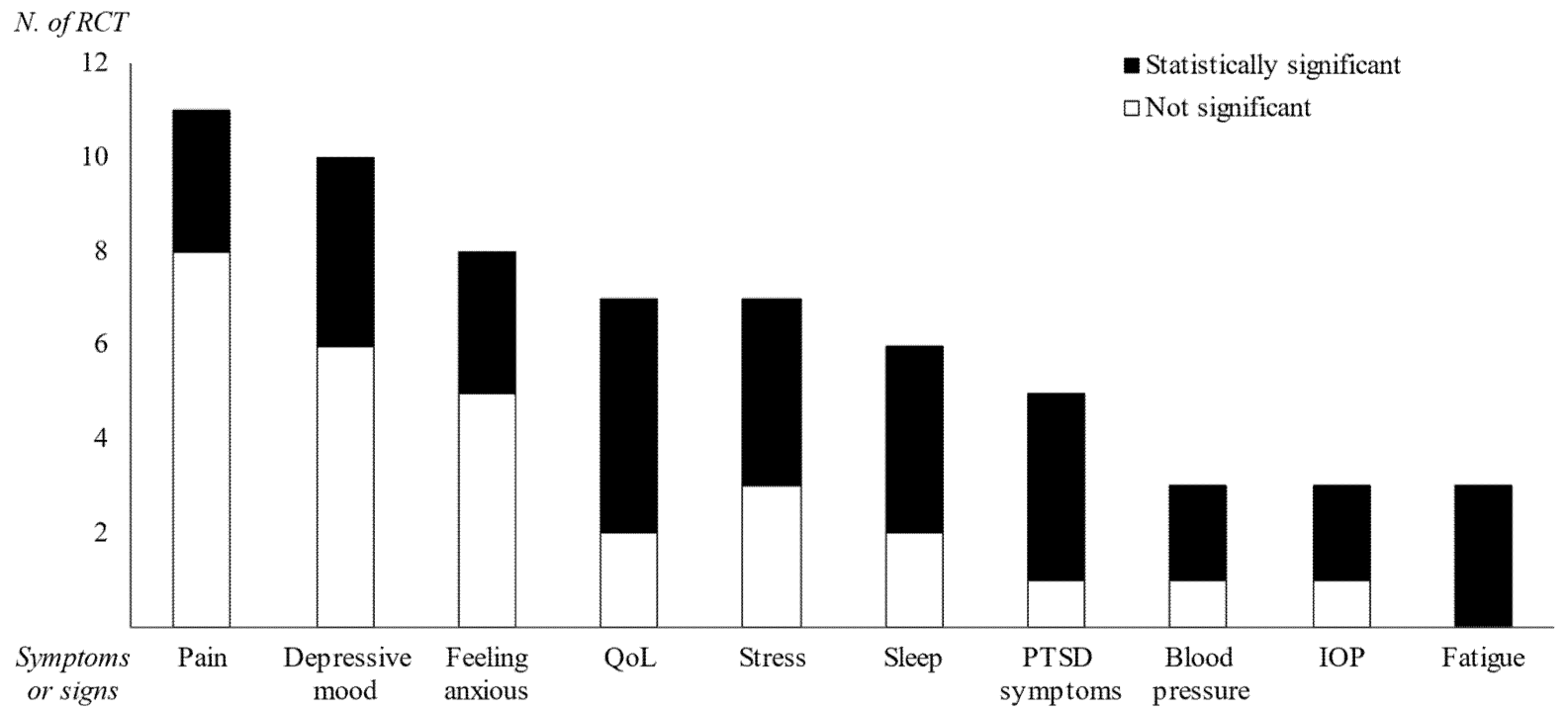

Figure 2. Graphical display of the primary outcomes of the RCTs. Regarding only primary measurements, the 10 most frequently assessed symptoms or signs (conducted in $\geq 3$ RCTs) are shown. The black square ( $\boldsymbol{\square})$ indicates the number of RCTs in which the intervention achieved statistical significance compared to the control ( $p<0.05$ or Cohen's $d>0.5)$ for the primary outcome assessment.

In the sum of all measurements (406 measurements in 104 RCTs), depressive mood symptoms were most frequent (56 RCTs, 53.8\%), followed by feeling anxious (40 RCTs, $38.5 \%$ ), QoL (32 RCTs, 30.8\%), stress (31 RCTs, 29.8\%), sleep (23 RCTs, 22.1\%), pain (22 RCTs, $21.2 \%$ ) and fatigue (19 RCTs, 18.3\%) (Table 1).

\subsection{Clinical Outcomes for the Primary Measurement and Total Measurements}

From a total of 99 primary outcomes (41 kinds of measurements), the top 3 most frequent outcomes were pain, depressive mood, and feeling anxious, and they did not reach a $50 \%$ positive ratio $(27.3 \%, 40.0 \%$, and $37.5 \%$, respectively). QoL $(71.4 \%)$, stress $(57.1 \%)$, sleep $(66.7 \%)$, PTSD symptoms $(80.0 \%)$, blood pressure $(66.7 \%)$, IOP (66.7\%), and fatigue $(100.0 \%)$ showed over half the ratio of positive results (Figure 2 ).

As shown in Figure 3, RCTs for sleep and fatigue showed 100\% positive effects in RCTs with participants with mental disorders and showed a relatively high ratio of positive outcomes in all the RCTs (73.9\% and 68.4\%, respectively), followed by stress $(48.4 \%)$, depressive mood (42.9\%), pain (40.9\%), QoL (40.6\%), and feeling anxious $(35.0 \%)$. The positive ratios of depressive mood and stress symptoms were greater than $50 \%$ only for mental and physical diseases (57.9 and 56.5\% each) (Figure 3). 




Figure 3. The features of significant outcomes in the RCTs according to physical and mental disorders. Regarding all measurements, the seven most frequently assessed outcomes are displayed according to subjects with physical and mental disorders. The circle's size and level of darkness indicate the number of RCTs and the ratio of positive outcomes, respectively. The positive outcome indicates that the treatment achieved statistical significance compared to the control $(p<0.05$ or Cohen's d > 0.5). */\# indicates the total number of outcomes measured for the seven symptoms in the RCTs for patients with given disorders and positive outcomes and their ratios.

\subsection{Clinical Outcomes According to the Type of Meditation}

Among the three major meditative interventions, yoga-based interventions (53.7\% of 67 outcomes) showed slightly higher positive outcomes than mindfulness-based interventions ( $45.3 \%$ of 113 outcomes) and TM interventions (31.0\% of 29 outcomes). Compared to other symptoms, sleep-targeted RCTs most frequently employed mindfulness-based meditation (16 of $25 \mathrm{RCTs})$, which presented over half the ratio of positive results $(75.0 \%)$. Yogabased interventions showed higher positive results regarding depressive mood (56.3\%). RCTs for sleep and fatigue showed $100 \%$ of significant benefits by mindfulness-based meditation and TM (Figure 4). 




Figure 4. The features of significant outcomes in the RCTs according to the types of meditations. Regarding all measurements, the seven most frequently assessed outcomes are displayed according to the types of meditations. The circle's size and level of darkness indicate the number of RCTs and the ratio of positive outcomes, respectively. The positive outcome indicates that treatment achieved statistical significance compared to the control $(p<0.05$ or Cohen's $d>0.5)$. * $/$ indicates the total number of outcomes measured for the seven symptoms in the RCTs for patients with given disorders and positive outcomes, and their ratio.

\section{Discussion}

Research on the physiological effects of meditation was first conducted in the 1950s, and a clinical study was initiated in the 1970s [118]. While CAM is becoming increasingly popular, so does the employment of meditation for disease therapy currently representing a quarter of the total CAM uses [119]. Although numerous studies have been conducted to investigate the clinical benefits of meditation, the standardization of its benefits is still challenging because of the heterogeneity and methodological weaknesses [11]. To provide fundamental information for future clinical use and study, this review aimed to produce features of clinical applications with meditation using RCTs for especially diseased populations to date.

The trials included in this study gradually increased from 3 RCTs over a 5 year period from 2000 to 2004 to 52 RCTs in the period from 2015 to 2019 (data not shown). The sex ratio of participants showed an approximately twofold higher distribution in females (7022 out of a total of 10,139), generally correlating with sex differences in the prevalence of meditation use [120]. The 104 RCTs included in this study involved 45 kinds of disease conditions, and $43 \mathrm{RCTs}$ assessed the primary outcomes directly related to the target diseases/disorders, such as pain for arthritis [33,44], sleep quality for sleep disturbance [114], and the PTSD-symptom scale for people living with PTSD [13,101-103]. Several RCTs evaluated objective changes by assessing blood markers, heart rate variability $[12,32,59,61,72,74,76,77,92,93,103]$, or brain imaging scans [53], as summarized in Tables 2 and 3. The others mainly focused on disease-related comorbid symptoms, including depressive mood, feeling anxious, QoL, and stress (Figure 2). 
The top 7 most frequently assessed clinical outcomes included depressive mood, feeling anxious, QoL, stress, sleep, pain, and fatigue, and at least 1 of them was measured in $87.5 \%$ (91 RCTs) of the 104 RCTs. These symptoms have a high prevalence in both diseased and healthy populations. For example, US survey data presented prevalence rates of $21 \%$, $25 \%$, and $33 \%$ for depressive mood, fatigue, and pain, respectively, in subjects with a cancer history and 18\%,18\%, and 29\% in adults without a cancer history, respectively [121]. Patients usually complained of clusters of several symptoms simultaneously; accordingly, most RCTs had multiple outcomes, with an average of $3.9 \pm 2.5$ measurements (Table 1 ). Mind-body interventions such as relaxation, cognitive behavioral therapy, coping skills training, or meditation helped patients manage symptom clusters of pain-fatigue-sleep disturbance in cancer patients [122].

Meditative interventions are usually expected to promote strengths in tolerating individual torments by reinforcing the psychological capacity of self-regulation [123]. In our data, meditations most frequently targeted depressive mood and feeling anxious, which were known as the most common comorbid symptoms in the population under disease conditions $[124,125]$. Both complaints were significantly improved by meditation practices by $42.9 \%$ and $35.0 \%$, respectively, and the anti-depressive effect was more prominent in patients with mental disorders (57.9\%) than in those with physical disorders (35.1\%) (Figure 3). The therapeutic mechanisms of meditation against major depressive disorders are understood as upregulation of serotonin and dopamine along with neuro-immunoendocrinological modulation [126]. Sleep quality and fatigue-related benefits were the most positive in the current study by $73.9 \%$ and $68.4 \%$, respectively, which increased further in subjects with mental disorders (100.0\% both) (Figure 3). In disease conditions, sleep-requiring symptoms such as fatigue and lethargy are common complaints as pathophysiological defense responses [127]. The role of meditation in sleep quality is understood as changing sleep architecture by regulating brain activities [128]. Accumulated evidence indicates that meditative interventions could lead to functional and structural changes within the brain, such as the prefrontal region, cingulate cortex, striatum, and amygdala, suggesting its promising therapeutic effect on mental disorders [129].

In terms of QoL and stress symptoms, they are the main reasons for the use of meditation by meditation practitioners in the US [120]. The benefits of mindfulness- and yoga-based programs for stress reduction and global wellness in nonclinical populations are widely and well-known [130,131]. However, our data suggest that meditative interventions did not consistently improve QoL or stress symptoms in disease conditions. Perhaps disease-related QoL and stress differ from those of healthy conditions due to the intensity of root matters such as histological and functional impairments [132]. Several RCTs on gynecological disease $[62,64,67]$ and PTSD [103,104], however, showed fragmentary evidence to support the stress reduction effect without ineffective outcomes (Tables 2 and 3).

In general, RCTs for physical disease included more than two mental disorders (74 physical vs. 31 mental diseases). Among them, cancer, musculoskeletal or connective tissue, and nervous system diseases were dominant (16, 14, and 9 RCTs, respectively) (Table 1). For patients with cancer, meditation is one of the preferred CAMs with the highest satisfaction [133]. In our data, the interventions showed a decent ratio of positive results (positive, 8 , vs. not significant, 2) in terms of cancer-related fatigue (CRF) (Table 2). Regarding the pain relief effect, the most of RCTs evaluating pain were for diseases of the musculoskeletal, connective tissue, and nervous system (13 RCTs out of 22). Although they failed to present consistent benefits (7 positive vs. 6 not significant), this ratio was higher than that in other diseases (2 vs. 6) (Figure 3, Tables 2 and 3).

Overall, according to our data, meditative therapies appear to be more beneficial for improving sleep quality and fatigue management as well as anti-depressive effects, especially in patients suffering from mental disorders. The conceptual basis of meditations includes attention, awareness, point of focus, or self-transcendence, even though they vary depending on historical and regional beliefs and methodological heterogenicity [134]. When we compared the gross features of three major meditation classifications, approx- 
imately $50 \%$ of the RCTs (51 RCTs) employed mindfulness-based meditation (Table 1). Compared to other symptoms, sleep-targeted RCTs (64\%) mainly employed mindfulnessbased meditation, resulting in relatively high positive results $(75.0 \%)$. The second most frequently applied type of intervention was yoga-based interventions, which were more beneficial for depressive mood (56.3\%) than other interventions (Figure 4$)$. In general, physical exercise therapies are recommended for patients suffering from most diseases, including cancer, fibromyalgia, and multiple sclerosis [135-137]. However, they could often worsen certain symptoms, such as fatigue, or occasionally cause other physical adverse effects [138]. Some studies have shown that managing concurrent symptoms well has a medical impact, including on the final clinical outcome; for example, reducing fatigue severity affects the survival or recurrence rate in breast cancer patients [139]. In this regard, meditation could be a promising alternative to manage subjective complaints in people living with various diseases.

This review has several limitations. First, a single database (PubMed) was used for the literature survey. Although the majority of data were extracted from the PubMed database, more evidence could be provided by other databases. We also found that the generally poor design quality of the studies remains a weakness. In this review, the number of articles were reduced by two-thirds in the screening process with Jadad scores (Figure 1). Further rigorously designed clinical trials are needed to objectify the clinical benefits of meditation. To provide confident information, pilot RCTs were excluded from this review. They commonly enrolled a small number of participants, focusing mainly on the feasibility of further trials. However, this tactic also has a risk of losing any valuable data.

Despite the limitations mentioned above, this review produced the comprehensive features regarding patients, interventions, controls, measurements, and their overall benefits in diseased populations. These results provide fundamental information to patients, practitioners, and researchers as reference data for future studies.

Author Contributions: D.-Y.K., S.-H.H., S.-H.J., S.-H.P., H.-J.J., J.-H.N. and J.-M.S. searched the literature; D.-Y.K., S.-H.H. and S.-H.J. extracted and analyzed the data; S.-H.P., H.-J.J., J.-H.N. and J.-M.S. participated in the discussion; D.-Y.K. and S.-H.H. wrote the manuscript; E.-J.L. and C.-G.S. supervised the whole process of this study with the initial design. All authors have read and agreed to the published version of the manuscript.

Funding: This work was supported by the National Research Foundation of Korea (NRF) grant funded by the Ministry of Science, ICT \& Future Planning (NRF-2018R1A6A1A03025221).

Conflicts of Interest: The authors declare no conflict of interest.

\section{References}

1. Brandmeyer, T.; Delorme, A.; Wahbeh, H. The neuroscience of meditation: Classification, phenomenology, correlates, and mechanisms. Prog. Brain Res. 2019, 244, 1-29. [PubMed]

2. Goyal, M.; Singh, S.; Sibinga, E.M.; Gould, N.F.; Rowland-Seymour, A.; Sharma, R.; Berger, Z.; Sleicher, D.; Maron, D.D.; Shihab, H.M. Meditation programs for psychological stress and well-being: A systematic review and meta-analysis. JAMA Intern. Med. 2014, 174, 357-368. [CrossRef] [PubMed]

3. Ospina, M.B.; Bond, K.; Karkhaneh, M.; Tjosvold, L.; Vandermeer, B.; Liang, Y.; Bialy, L.; Hooton, N.; Buscemi, N.; Dryden, D.M. Meditation practices for health: State of the research. Evid. Rep./Technol. Assess. 2007, 155, 1-263.

4. $\quad$ Clarke, T.C.; Barnes, P.M.; Black, L.I.; Stussman, B.J.; Nahin, R.L. Use of Yoga, Meditation, and Chiropractors among US Adults Aged 18 and Over; Department of Health and Human Services, Centers for Disease Control and Prevention, National Center for Health Statistics: Hyattsville, MD, USA, 2018.

5. McConnell, B.; Applegate, M.; Keniston, A.; Kluger, B.; Maa, E. Use of complementary and alternative medicine in an urban county hospital epilepsy clinic. Epilepsy Behav. 2014, 34, 73-76. [CrossRef] [PubMed]

6. Chi, X.; Bo, A.; Liu, T.; Zhang, P.; Chi, I. Effects of mindfulness-based stress reduction on depression in adolescents and young adults: A systematic review and meta-analysis. Front. Psychol. 2018, 9, 1034. [CrossRef] [PubMed]

7. Piet, J.; Würtzen, H.; Zachariae, R. The effect of mindfulness-based therapy on symptoms of anxiety and depression in adult cancer patients and survivors: A systematic review and meta-analysis. J. Consult. Clin. Psychol. 2012, 80, 1007. [CrossRef]

8. Cramer, H.; Lauche, R.; Haller, H.; Steckhan, N.; Michalsen, A.; Dobos, G. Effects of yoga on cardiovascular disease risk factors: A systematic review and meta-analysis. Int. J. Cardiol. 2014, 173, 170-183. [CrossRef] [PubMed] 
9. Desai, R.; Tailor, A.; Bhatt, T. Effects of yoga on brain waves and structural activation: A review. Complement. Ther. Clin. Pract. 2015, 21, 112-118. [CrossRef] [PubMed]

10. Matko, K.; Sedlmeier, P. What is meditation? Proposing an empirically derived classification system. Front. Psychol. 2019, 10, 2276. [CrossRef] [PubMed]

11. Ospina, M.B.; Bond, K.; Karkhaneh, M.; Buscemi, N.; Dryden, D.M.; Barnes, V.; Carlson, L.E.; Dusek, J.A.; Shannahoff-Khalsa, D. Clinical trials of meditation practices in health care: Characteristics and quality. J. Altern. Complement. Med. 2008, 14, 1199-1213. [CrossRef] [PubMed]

12. Ionson, E.; Limbachia, J.; Rej, S.; Puka, K.; Newman, R.I.; Wetmore, S.; Burhan, A.M.; Vasudev, A. Effects of Sahaj Samadhi meditation on heart rate variability and depressive symptoms in patients with late-life depression. Br. J. Psychiatry 2019, 214, 218-224. [CrossRef]

13. Nidich, S.; Mills, P.J.; Rainforth, M.; Heppner, P.; Schneider, R.H.; Rosenthal, N.E.; Salerno, J.; Gaylord-King, C.; Rutledge, T. Non-trauma-focused meditation versus exposure therapy in veterans with post-traumatic stress disorder: A randomised controlled trial. Lancet Psychiatry 2018, 5, 975-986. [CrossRef]

14. Page, M.J.; McKenzie, J.E.; Bossuyt, P.M.; Boutron, I.; Hoffmann, T.C.; Mulrow, C.D.; Shamseer, L.; Tetzlaff, J.M.; Akl, E.A.; Brennan, S.E. The PRISMA 2020 statement: An updated guideline for reporting systematic reviews. BMJ 2021, 372, n71. [CrossRef] [PubMed]

15. Clark, H.D.; Wells, G.A.; Huët, C.; McAlister, F.A.; Salmi, L.R.; Fergusson, D.; Laupacis, A. Assessing the quality of randomized trials: Reliability of the Jadad scale. Control. Clin. Trials 1999, 20, 448-452. [CrossRef]

16. Henneghan, A.M.; Becker, H.; Harrison, M.L.; Inselmann, K.; Fico, B.; Schafer, H.; King, E.; Patt, D.; Kesler, S. A randomized control trial of meditation compared to music listening to improve cognitive function for breast cancer survivors: Feasibility and acceptability. Complement. Ther. Clin. Pract. 2020, 41, 101228. [CrossRef] [PubMed]

17. Gok, M.Z.; Karadas, C.; Izgu, N.; Ozdemir, L.; Demirci, U. Effects of progressive muscle relaxation and mindfulness meditation on fatigue, coping styles, and quality of life in early breast cancer patients: An assessor blinded, three-arm, randomized controlled trial. Eur. J. Oncol. Nurs. Off. J. Eur. Oncol. Nurs. Soc. 2019, 42, 116.

18. Stoerkel, E.; Bellanti, D.; Paat, C.; Peacock, K.; Aden, J.; Setlik, R.; Walter, J.; Inman, A. Effectiveness of a self-care toolkit for surgical breast cancer patients in a military treatment facility. J. Altern. Complement. Med. 2018, 24, 916-925. [CrossRef] [PubMed]

19. Irwin, M.R.; Olmstead, R.; Carrillo, C.; Sadeghi, N.; Nicassio, P.; Ganz, P.A.; Bower, J.E. Tai Chi Chih compared with cognitive behavioral therapy for the treatment of insomnia in survivors of breast cancer: A randomized, partially blinded, noninferiority trial. J. Clin. Oncol. 2017, 35, 2656. [CrossRef]

20. Rao, R.M.; Raghuram, N.; Nagendra, H.R.; Kodaganur, G.S.; Bilimagga, R.S.; Shashidhara, H.; Diwakar, R.B.; Patil, S.; Rao, N. Effects of a yoga program on mood states, quality of life, and toxicity in breast cancer patients receiving conventional treatment: A randomized controlled trial. Indian J. Palliat. Care 2017, 23, 237. [CrossRef]

21. Cramer, H.; Rabsilber, S.; Lauche, R.; Kümmel, S.; Dobos, G. Yoga and meditation for menopausal symptoms in breast cancer survivors-a randomized controlled trial. Cancer 2015, 121, 2175-2184. [CrossRef] [PubMed]

22. Peppone, L.J.; Janelsins, M.C.; Kamen, C.; Mohile, S.G.; Sprod, L.K.; Gewandter, J.S.; Kirshner, J.J.; Gaur, R.; Ruzich, J.; Esparaz, B.T. The effect of YOCAS ${ }^{\circledR}$ yoga for musculoskeletal symptoms among breast cancer survivors on hormonal therapy. Breast Cancer Res. Treat. 2015, 150, 597-604. [CrossRef]

23. Larkey, L.K.; Roe, D.J.; Weihs, K.L.; Jahnke, R.; Lopez, A.M.; Rogers, C.E.; Oh, B.; Guillen-Rodriguez, J. Randomized controlled trial of Qigong/Tai Chi Easy on cancer-related fatigue in breast cancer survivors. Ann. Behav. Med. 2015, 49, 165-176. [CrossRef]

24. Bower, J.E.; Crosswell, A.D.; Stanton, A.L.; Crespi, C.M.; Winston, D.; Arevalo, J.; Ma, J.; Cole, S.W.; Ganz, P.A. Mindfulness meditation for younger breast cancer survivors: A randomized controlled trial. Cancer 2015, 121, 1231-1240. [CrossRef]

25. Carlson, L.E.; Doll, R.; Stephen, J.; Faris, P.; Tamagawa, R.; Drysdale, E.; Speca, M. Randomized controlled trial of mindfulnessbased cancer recovery versus supportive expressive group therapy for distressed survivors of breast cancer. J. Clin. Oncol. 2013, 31, 3119-3126. [CrossRef]

26. Mustian, K.M.; Sprod, L.K.; Janelsins, M.; Peppone, L.J.; Palesh, O.G.; Chandwani, K.; Reddy, P.S.; Melnik, M.K.; Heckler, C.; Morrow, G.R. Multicenter, randomized controlled trial of yoga for sleep quality among cancer survivors. J. Clin. Oncol. 2013, 31, 3233. [CrossRef] [PubMed]

27. Andersen, S.R.; Würtzen, H.; Steding-Jessen, M.; Christensen, J.; Andersen, K.K.; Flyger, H.; Mitchelmore, C.; Johansen, C.; Dalton, S.O. Effect of mindfulness-based stress reduction on sleep quality: Results of a randomized trial among Danish breast cancer patients. Acta Oncol. 2013, 52, 336-344. [CrossRef] [PubMed]

28. Kim, Y.H.; Kim, H.J.; Do Ahn, S.; Seo, Y.J.; Kim, S.H. Effects of meditation on anxiety, depression, fatigue, and quality of life of women undergoing radiation therapy for breast cancer. Complement. Ther. Med. 2013, 21, 379-387. [CrossRef] [PubMed]

29. Bränström, R.; Kvillemo, P.; Moskowitz, J.T. A randomized study of the effects of mindfulness training on psychological wellbeing and symptoms of stress in patients treated for cancer at 6-month follow-up. Int. J. Behav. Med. 2012, 19, 535-542. [CrossRef] [PubMed]

30. Nidich, S.I.; Fields, J.Z.; Rainforth, M.V.; Pomerantz, R.; Cella, D.; Kristeller, J.; Salerno, J.W.; Schneider, R.H. A randomized controlled trial of the effects of transcendental meditation on quality of life in older breast cancer patients. Integr. Cancer Ther. 2009, 8, 228-234. [CrossRef] 
31. Speca, M.; Carlson, L.E.; Goodey, E.; Angen, M. A randomized, wait-list controlled clinical trial: The effect of a mindfulness meditation-based stress reduction program on mood and symptoms of stress in cancer outpatients. Psychosom. Med. 2000, 62, 613-622. [CrossRef]

32. Gautam, S.; Tolahunase, M.; Kumar, U.; Dada, R. Impact of yoga based mind-body intervention on systemic inflammatory markers and co-morbid depression in active Rheumatoid arthritis patients: A randomized controlled trial. Restor. Neurol. Neurosci. 2019, 37, 41-59. [CrossRef]

33. Innes, K.E.; Selfe, T.K.; Kandati, S.; Wen, S.; Huysmans, Z. Effects of mantra meditation versus music listening on knee pain, function, and related outcomes in older adults with knee osteoarthritis: An exploratory Randomized Clinical Trial (RCT). Evid.-Based Complement. Altern. Med. 2018, 2018, 7683897. [CrossRef]

34. Van Gordon, W.; Shonin, E.; Dunn, T.J.; Garcia-Campayo, J.; Griffiths, M.D. Meditation awareness training for the treatment of fibromyalgia syndrome: A randomized controlled trial. Br. J. Health Psychol. 2017, 22, 186-206. [CrossRef]

35. Cherkin, D.C.; Sherman, K.J.; Balderson, B.H.; Cook, A.J.; Anderson, M.L.; Hawkes, R.J.; Hansen, K.E.; Turner, J.A. Effect of mindfulness-based stress reduction vs cognitive behavioral therapy or usual care on back pain and functional limitations in adults with chronic low back pain: A randomized clinical trial. JAMA 2016, 315, 1240-1249. [CrossRef]

36. Michalsen, A.; Kunz, N.; Jeitler, M.; Brunnhuber, S.; Meier, L.; Lüdtke, R.; Büssing, A.; Kessler, C. Effectiveness of focused meditation for patients with chronic low back pain-a randomized controlled clinical trial. Complement. Ther. Med. 2016, 26, 79-84. [CrossRef] [PubMed]

37. Cash, E.; Salmon, P.; Weissbecker, I.; Rebholz, W.N.; Bayley-Veloso, R.; Zimmaro, L.A.; Floyd, A.; Dedert, E.; Sephton, S.E. Mindfulness meditation alleviates fibromyalgia symptoms in women: Results of a randomized clinical trial. Ann. Behav. Med. 2015, 49, 319-330. [CrossRef] [PubMed]

38. Jeitler, M.; Brunnhuber, S.; Meier, L.; Lüdtke, R.; Büssing, A.; Kessler, C.; Michalsen, A. Effectiveness of jyoti meditation for patients with chronic neck pain and psychological distress-A randomized controlled clinical trial. J. Pain 2015, 16, 77-86. [CrossRef]

39. la Cour, P.; Petersen, M. Effects of mindfulness meditation on chronic pain: A randomized controlled trial. Pain Med. 2015, 16, 641-652. [CrossRef] [PubMed]

40. Ebnezar, J.; Nagarathna, R.; Bali, Y.; Nagendra, H.R. Effect of an integrated approach of yoga therapy on quality of life in osteoarthritis of the knee joint: A randomized control study. Int. J. Yoga 2011, 4, 55. [CrossRef] [PubMed]

41. Wong, S.Y.-S.; Chan, F.W.-K.; Wong, R.L.-P.; Chu, M.-C.; Lam, Y.-Y.K.; Mercer, S.W.; Ma, S.H. Comparing the effectiveness of mindfulness-based stress reduction and multidisciplinary intervention programs for chronic pain: A randomized comparative trial. Clin. J. Pain 2011, 27, 724-734. [CrossRef]

42. Schmidt, S.; Grossman, P.; Schwarzer, B.; Jena, S.; Naumann, J.; Walach, H. Treating fibromyalgia with mindfulness-based stress reduction: Results from a 3-armed randomized controlled trial. Pain 2011, 152, 361-369. [CrossRef] [PubMed]

43. Tekur, P.; Singphow, C.; Nagendra, H.R.; Raghuram, N. Effect of short-term intensive yoga program on pain, functional disability and spinal flexibility in chronic low back pain: A randomized control study. J. Altern. Complement. Med. 2008, 14, 637-644. [CrossRef]

44. Zautra, A.J.; Davis, M.C.; Reich, J.W.; Nicassario, P.; Tennen, H.; Finan, P.; Kratz, A.; Parrish, B.; Irwin, M.R. Comparison of cognitive behavioral and mindfulness meditation interventions on adaptation to rheumatoid arthritis for patients with and without history of recurrent depression. J. Consult. Clin. Psychol. 2008, 76, 408. [CrossRef]

45. Pradhan, E.K.; Baumgarten, M.; Langenberg, P.; Handwerger, B.; Gilpin, A.K.; Magyari, T.; Hochberg, M.C.; Berman, B.M. Effect of mindfulness-based stress reduction in rheumatoid arthritis patients. Arthritis Care Res. 2007, 57, 1134-1142. [CrossRef]

46. Cherup, N.P.; Strand, K.L.; Lucchi, L.; Wooten, S.V.; Luca, C.; Signorile, J.F. Yoga Meditation Enhances Proprioception and Balance in Individuals Diagnosed with Parkinson's Disease. Percept. Mot. Ski. 2021, 128, 304-323. [CrossRef]

47. Jong, M.C.; Boers, I.; van Wietmarschen, H.; Tromp, E.; Busari, J.; Wennekes, R.; Snoeck, I.; Bekhof, J.; Vlieger, A. Hypnotherapy or transcendental meditation versus progressive muscle relaxation exercises in the treatment of children with primary headaches: A multi-centre, pragmatic, randomised clinical study. Eur. J. Pediatr. 2019, 178, 147-154. [CrossRef] [PubMed]

48. Cavalera, C.; Rovaris, M.; Mendozzi, L.; Pugnetti, L.; Garegnani, M.; Castelnuovo, G.; Molinari, E.; Pagnini, F. Online meditation training for people with multiple sclerosis: A randomized controlled trial. Mult. Scler. J. 2019, 25, 610-617. [CrossRef] [PubMed]

49. Wachholtz, A.B.; Malone, C.D.; Pargament, K.I. Effect of different meditation types on migraine headache medication use. Behav. Med. 2017, 43, 1-8. [CrossRef]

50. Pagnini, F.; Marconi, A.; Tagliaferri, A.; Manzoni, G.M.; Gatto, R.; Fabiani, V.; Gragnano, G.; Rossi, G.; Volpato, E.; Banfi, P. Meditation training for people with amyotrophic lateral sclerosis: A randomized clinical trial. Eur. J. Neurol. 2017, 24, 578-586. [CrossRef]

51. Advocat, J.; Enticott, J.; Vandenberg, B.; Hassed, C.; Hester, J.; Russell, G. The effects of a mindfulness-based lifestyle program for adults with Parkinson's disease: A mixed methods, wait list controlled randomised control study. BMC Neurol. 2016, 16, 166. [CrossRef]

52. Najafidoulatabad, S.; Mohebbi, Z. Yoga effects on physical activity and sexual satisfaction among Iranian women with multiple sclerosis: A randomized controlled trial. Afr. J. Tradit. Complement. Altern. Med. 2014, 11, 78-82. [CrossRef] 
53. Pickut, B.A.; Van Hecke, W.; Kerckhofs, E.; Mariën, P.; Vanneste, S.; Cras, P.; Parizel, P.M. Mindfulness based intervention in Parkinson's disease leads to structural brain changes on MRI: A randomized controlled longitudinal trial. Clin. Neurol. Neurosurg. 2013, 115, 2419-2425. [CrossRef]

54. Wachholtz, A.B.; Pargament, K.I. Migraines and meditation: Does spirituality matter? J. Behav. Med. 2008, 31, 351-366. [CrossRef]

55. Lee, S.Y.; Kang, J. Effect of virtual reality meditation on sleep quality of intensive care unit patients: A randomised controlled trial. Intensive Crit. Care Nurs. 2020, 59, 102849. [CrossRef]

56. Cramer, H.; Sellin, C.; Schumann, D.; Dobos, G. Yoga in arterial hypertension: A three-armed, randomized controlled trial. Dtsch Ärzteblatt Int. 2018, 115, 833.

57. Blom, K.; Baker, B.; How, M.; Dai, M.; Irvine, J.; Abbey, S.; Abramson, B.L.; Myers, M.G.; Kiss, A.; Perkins, N.J. Hypertension analysis of stress reduction using mindfulness meditation and yoga: Results from the harmony randomized controlled trial. Am. J. Hypertens. 2014, 27, 122-129. [CrossRef]

58. Jayadevappa, R.; Johnson, J.C.; Bloom, B.S.; Nidich, S.; Desai, S.; Chhatre, S.; Raziano, D.B.; Schneider, R.H. Effectiveness of transcendental meditation on functional capacity and quality of life of African Americans with congestive heart failure: A randomized control study. Ethn. Dis. 2007, 17, 72. [PubMed]

59. Paul-Labrador, M.; Polk, D.; Dwyer, J.H.; Velasquez, I.; Nidich, S.; Rainforth, M.; Schneider, R.; Merz, C.N.B. Effects of a randomized controlled trial of transcendental meditation on components of the metabolic syndrome in subjects with coronary heart disease. Arch. Intern. Med. 2006, 166, 1218-1224. [CrossRef] [PubMed]

60. Schneider, R.H.; Alexander, C.N.; Staggers, F.; Orme-Johnson, D.W.; Rainforth, M.; Salerno, J.W.; Sheppard, W.; Castillo-Richmond, A.; Barnes, V.A.; Nidich, S.I. A randomized controlled trial of stress reduction in African Americans treated for hypertension for over one year. Am. J. Hypertens. 2005, 18, 88-98. [CrossRef] [PubMed]

61. Castillo-Richmond, A.; Schneider, R.H.; Alexander, C.N.; Cook, R.; Myers, H.; Nidich, S.; Haney, C.; Rainforth, M.; Salerno, J. Effects of stress reduction on carotid atherosclerosis in hypertensive African Americans. Stroke 2000, 31, 568-573. [CrossRef] [PubMed]

62. Smith, R.B.; Mahnert, N.D.; Foote, J.; Saunders, K.T.; Mourad, J.; Huberty, J. Mindfulness Effects in Obstetric and Gynecology Patients During the Coronavirus Disease 2019 (COVID-19) Pandemic: A Randomized Controlled Trial. Obstet. Gynecol. 2021, 137, 1032. [CrossRef] [PubMed]

63. Forbes, G.; Newton, S.; Calvete, C.C.; Birch, J.; Dodds, J.; Steed, L.; Rivas, C.; Khan, K.; Röhricht, F.; Taylor, S. MEMPHIS: A smartphone app using psychological approaches for women with chronic pelvic pain presenting to gynaecology clinics: A randomised feasibility trial. BMJ Open 2020, 10, e030164. [CrossRef] [PubMed]

64. Yang, N.-Y.; Kim, S.-D. Effects of a yoga program on menstrual cramps and menstrual distress in undergraduate students with primary dysmenorrhea: A single-blind, randomized controlled trial. J. Altern. Complement. Med. 2016, 22, 732-738. [CrossRef] [PubMed]

65. Jayabharathi, B.; Judie, A. Complementary health approach to quality of life in menopausal women: A community-based interventional study. Clin. Interv. Aging 2014, 9, 1913. [CrossRef] [PubMed]

66. Joshi, S.; Khandwe, R.; Bapat, D.; Deshmukh, U. Effect of yoga on menopausal symptoms. Menopause Int. 2011, 17, 78-81. [CrossRef]

67. Chattha, R.; Raghuram, N.; Venkatram, P.; Hongasandra, N.R. Treating the climacteric symptoms in Indian women with an integrated approach to yoga therapy: A randomized control study. Menopause 2008, 15, 862-870. [CrossRef] [PubMed]

68. Chattha, R.; Nagarathna, R.; Padmalatha, V.; Nagendra, H. Effect of yoga on cognitive functions in climacteric syndrome: A randomised control study. BJOG Int. J. Obstet. Gynaecol. 2008, 115, 991-1000. [CrossRef] [PubMed]

69. Izgu, N.; Gok Metin, Z.; Karadas, C.; Ozdemir, L.; Metinarikan, N.; Corapcioglu, D. Progressive muscle relaxation and mindfulness meditation on neuropathic pain, fatigue, and quality of life in patients with type 2 diabetes: A randomized clinical trial. J. Nurs. Scholarsh. 2020, 52, 476-487. [CrossRef]

70. Imeni, M.; Sabouhi, F.; Abazari, P.; Iraj, B. The effect of spiritual care on the body image of patients undergoing amputation due to type 2 diabetes: A randomized clinical trial. Iran. J. Nurs. Midwifery Res. 2018, 23, 322. [PubMed]

71. Adler, E.; Dhruva, A.; Moran, P.J.; Daubenmier, J.; Acree, M.; Epel, E.S.; Bacchetti, P.; Prather, A.A.; Mason, A.; Hecht, F.M. Impact of a mindfulness-based weight-loss intervention on sleep quality among adults with obesity: Data from the SHINE randomized controlled trial. J. Altern. Complement. Med. 2017, 23, 188-195. [CrossRef] [PubMed]

72. Jung, H.Y.; Lee, H.; Park, J. Comparison of the effects of $\mathrm{K}$ orean mindfulness-based stress reduction, walking, and patient education in diabetes mellitus. Nurs. Health Sci. 2015, 17, 516-525. [CrossRef] [PubMed]

73. Miller, C.K.; Kristeller, J.L.; Headings, A.; Nagaraja, H. Comparison of a mindful eating intervention to a diabetes self-management intervention among adults with type 2 diabetes: A randomized controlled trial. Health Educ. Behav. 2014, 41, 145-154. [CrossRef] [PubMed]

74. Vaccarino, V.; Kondwani, K.A.; Kelley, M.E.; Murrah, N.V.; Boyd, L.; Ahmed, Y.; Meng, Y.X.; Gibbons, G.H.; Hooper, W.C.; De Staercke, C. Effect of meditation on endothelial function in Black Americans with metabolic syndrome: A randomized trial. Psychosom. Med. 2013, 75, 591. [CrossRef]

75. Dada, T.; Bhai, N.; Midha, N.; Shakrawal, J.; Kumar, M.; Chaurasia, P.; Gupta, S.; Angmo, D.; Yadav, R.; Dada, R. Effect of mindfulness meditation on intraocular pressure and trabecular meshwork gene expression: A randomized controlled trial. Am. J. Ophthalmol. 2021, 223, 308-321. [CrossRef] [PubMed] 
76. Gagrani, M.; Faiq, M.A.; Sidhu, T.; Dada, R.; Yadav, R.K.; Sihota, R.; Kochhar, K.P.; Verma, R.; Dada, T. Meditation enhances brain oxygenation, upregulates BDNF and improves quality of life in patients with primary open angle glaucoma: A randomized controlled trial. Restor. Neurol. Neurosci. 2018, 36, 741-753. [CrossRef]

77. Dada, T.; Mittal, D.; Mohanty, K.; Faiq, M.A.; Bhat, M.A.; Yadav, R.K.; Sihota, R.; Sidhu, T.; Velpandian, T.; Kalaivani, M. Mindfulness meditation reduces intraocular pressure, lowers stress biomarkers and modulates gene expression in glaucoma: A randomized controlled trial. J. Glaucoma 2018, 27, 1061-1067. [CrossRef] [PubMed]

78. Arif, M.; Sadlier, M.; Rajenderkumar, D.; James, J.; Tahir, T. A randomised controlled study of mindfulness meditation versus relaxation therapy in the management of tinnitus. J. Laryngol. Otol. 2017, 131, 501-507. [CrossRef] [PubMed]

79. McKenna, L.; Marks, E.M.; Hallsworth, C.A.; Schaette, R. Mindfulness-based cognitive therapy as a treatment for chronic tinnitus: A randomized controlled trial. Psychother. Psychosom. 2017, 86, 351-361. [CrossRef] [PubMed]

80. Haisley, K.R.; Straw, O.J.; Müller, D.T.; Antiporda, M.A.; Zihni, A.M.; Reavis, K.M.; Bradley, D.D.; Dunst, C.M. Feasibility of implementing a virtual reality program as an adjuvant tool for peri-operative pain control; results of a randomized controlled trial in minimally invasive foregut surgery. Complement. Ther. Med. 2020, 49, 102356. [CrossRef]

81. Korterink, J.J.; Ockeloen, L.E.; Hilbink, M.; Benninga, M.A.; Deckers-Kocken, J.M. Yoga therapy for abdominal pain-related functional gastrointestinal disorders in children: A randomized controlled trial. J. Pediatr. Gastroenterol. Nutr. 2016, 63, 481-487. [CrossRef] [PubMed]

82. Berrill, J.W.; Sadlier, M.; Hood, K.; Green, J.T. Mindfulness-based therapy for inflammatory bowel disease patients with functional abdominal symptoms or high perceived stress levels. J. Crohn's Colitis 2014, 8, 945-955. [CrossRef] [PubMed]

83. Lin, F.L.; Yeh, M.L.; Lai, Y.H.; Lin, K.C.; Yu, C.J.; Chang, J.S. Two-month breathing-based walking improves anxiety, depression, dyspnoea and quality of life in chronic obstructive pulmonary disease: A randomised controlled study. J. Clin. Nurs. 2019, 28, 3632-3640. [CrossRef] [PubMed]

84. Kuloor, A.; Kumari, S.; Metri, K. Impact of yoga on psychopathologies and quality of life in persons with HIV: A randomized controlled study. J. Bodyw. Mov. Ther. 2019, 23, 278-283. [CrossRef] [PubMed]

85. Sudhanshu, A.; Sharma, U.; Vadiraja, H.; Rana, R.K.; Singhal, R. Impact of yoga on periodontal disease and stress management. Int. J. Yoga 2017, 10, 121. [CrossRef] [PubMed]

86. Gross, C.R.; Reilly-Spong, M.; Park, T.; Zhao, R.; Gurvich, O.V.; Ibrahim, H.N. Telephone-adapted Mindfulness-based Stress Reduction (tMBSR) for patients awaiting kidney transplantation. Contemp. Clin. Trials 2017, 57, 37-43. [CrossRef] [PubMed]

87. Brazier, A.; Mulkins, A.; Verhoef, M. Evaluating a yogic breathing and meditation intervention for individuals living with HIV / AIDS. Am. J. Health Promot. 2006, 20, 192-195. [CrossRef] [PubMed]

88. Manocha, R.; Marks, G.; Kenchington, P.; Peters, D.; Salome, C. Sahaja yoga in the management of moderate to severe asthma: A randomised controlled trial. Thorax 2002, 57, 110-115. [CrossRef]

89. Cullen, B.; Eichel, K.; Lindahl, J.R.; Rahrig, H.; Kini, N.; Flahive, J.; Britton, W.B. The contributions of focused attention and open monitoring in mindfulness-based cognitive therapy for affective disturbances: A 3-armed randomized dismantling trial. PLoS ONE 2021, 16, e244838. [CrossRef] [PubMed]

90. Bressington, D.; Mui, J.; Yu, C.; Leung, S.F.; Cheung, K.; Wu, C.S.T.; Bollard, M.; Chien, W.T. Feasibility of a group-based laughter yoga intervention as an adjunctive treatment for residual symptoms of depression, anxiety and stress in people with depression. J. Affect. Disord. 2019, 248, 42-51. [CrossRef] [PubMed]

91. Tolahunase, M.R.; Sagar, R.; Dada, R. 5-HTTLPR and MTHFR 677C > T polymorphisms and response to yoga-based lifestyle intervention in major depressive disorder: A randomized active-controlled trial. Indian J. Psychiatry 2018, 60, 410.

92. Tolahunase, M.R.; Sagar, R.; Faiq, M.; Dada, R. Yoga-and meditation-based lifestyle intervention increases neuroplasticity and reduces severity of major depressive disorder: A randomized controlled trial. Restor. Neurol. Neurosci. 2018, 36, 423-442. [CrossRef] [PubMed]

93. Chu, I.-H.; Wu, W.-L.; Lin, I.-M.; Chang, Y.-K.; Lin, Y.-J.; Yang, P.-C. Effects of yoga on heart rate variability and depressive symptoms in women: A randomized controlled trial. J. Altern. Complement. Med. 2017, 23, 310-316. [CrossRef] [PubMed]

94. Winnebeck, E.; Fissler, M.; Gärtner, M.; Chadwick, P.; Barnhofer, T. Brief training in mindfulness meditation reduces symptoms in patients with a chronic or recurrent lifetime history of depression: A randomized controlled study. Behav. Res. Ther. 2017, 99, 124-130. [CrossRef]

95. de Jong, M.; Lazar, S.W.; Hug, K.; Mehling, W.E.; Hölzel, B.K.; Sack, A.T.; Peeters, F.; Ashih, H.; Mischoulon, D.; Gard, T. Effects of mindfulness-based cognitive therapy on body awareness in patients with chronic pain and comorbid depression. Front. Psychol. 2016, 7, 967. [CrossRef] [PubMed]

96. Chiesa, A.; Castagner, V.; Andrisano, C.; Serretti, A.; Mandelli, L.; Porcelli, S.; Giommi, F. Mindfulness-based cognitive therapy vs. psycho-education for patients with major depression who did not achieve remission following antidepressant treatment. Psychiatry Res. 2015, 226, 474-483. [CrossRef] [PubMed]

97. Williams, J.M.G.; Crane, C.; Barnhofer, T.; Brennan, K.; Duggan, D.S.; Fennell, M.J.; Hackmann, A.; Krusche, A.; Muse, K.; Von Rohr, I.R. Mindfulness-based cognitive therapy for preventing relapse in recurrent depression: A randomized dismantling trial. J. Consult. Clin. Psychol. 2014, 82, 275. [CrossRef] [PubMed]

98. Britton, W.B.; Haynes, P.L.; Fridel, K.W.; Bootzin, R.R. Mindfulness-based cognitive therapy improves polysomnographic and subjective sleep profiles in antidepressant users with sleep complaints. Psychother. Psychosom. 2012, 81, 296-304. [CrossRef] [PubMed] 
99. Keune, P.M.; Bostanov, V.; Hautzinger, M.; Kotchoubey, B. Mindfulness-based cognitive therapy (MBCT), cognitive style, and the temporal dynamics of frontal EEG alpha asymmetry in recurrently depressed patients. Biol. Psychol. 2011, 88, 243-252. [CrossRef] [PubMed]

100. Britton, W.B.; Haynes, P.L.; Fridel, K.W.; Bootzin, R.R. Polysomnographic and subjective profiles of sleep continuity before and after mindfulness-based cognitive therapy in partially remitted depression. Psychosom. Med. 2010, 72, 539-548. [CrossRef] [PubMed]

101. Lang, A.J.; Malaktaris, A.L.; Casmar, P.; Baca, S.A.; Golshan, S.; Harrison, T.; Negi, L. Compassion meditation for posttraumatic stress disorder in veterans: A randomized proof of concept study. J. Trauma. Stress 2019, 32, 299-309. [CrossRef] [PubMed]

102. Bormann, J.E.; Thorp, S.R.; Smith, E.; Glickman, M.; Beck, D.; Plumb, D.; Zhao, S.; Ackland, P.E.; Rodgers, C.S.; Heppner, P. Individual treatment of posttraumatic stress disorder using mantram repetition: A randomized clinical trial. Am. J. Psychiatry 2018, 175, 979-988. [CrossRef] [PubMed]

103. Wahbeh, H.; Goodrich, E.; Goy, E.; Oken, B.S. Mechanistic pathways of mindfulness meditation in combat veterans with posttraumatic stress disorder. J. Clin. Psychol. 2016, 72, 365-383. [CrossRef] [PubMed]

104. Lee, M.Y.; Zaharlick, A.; Akers, D. Impact of meditation on mental health outcomes of female trauma survivors of interpersonal violence with co-occurring disorders: A randomized controlled trial. J. Interpers. Violence 2017, 32, 2139-2165. [CrossRef] [PubMed]

105. Seppälä, E.M.; Nitschke, J.B.; Tudorascu, D.L.; Hayes, A.; Goldstein, M.R.; Nguyen, D.T.; Perlman, D.; Davidson, R.J. Breathingbased meditation decreases posttraumatic stress disorder symptoms in US Military veterans: A randomized controlled longitudinal study. J. Trauma. Stress 2014, 27, 397-405. [CrossRef]

106. Catani, C.; Kohiladevy, M.; Ruf, M.; Schauer, E.; Elbert, T.; Neuner, F. Treating children traumatized by war and Tsunami: A comparison between exposure therapy and meditation-relaxation in North-East Sri Lanka. BMC Psychiatry 2009, 9, 22. [CrossRef]

107. Muratori, P.; Conversano, C.; Levantini, V.; Masi, G.; Milone, A.; Villani, S.; Bögels, S.; Gemignani, A. Exploring the efficacy of a mindfulness program for boys with attention-deficit hyperactivity disorder and oppositional defiant disorder. J. Atten. Disord. 2021, 25, 1544-1553. [CrossRef]

108. Janssen, L.; Kan, C.C.; Carpentier, P.J.; Sizoo, B.; Hepark, S.; Schellekens, M.P.; Donders, A.R.T.; Buitelaar, J.K.; Speckens, A.E. Mindfulness-based cognitive therapy v. treatment as usual in adults with ADHD: A multicentre, single-blind, randomised controlled trial. Psychol. Med. 2019, 49, 55-65. [CrossRef]

109. Hoxhaj, E.; Sadohara, C.; Borel, P.; D'Amelio, R.; Sobanski, E.; Müller, H.; Feige, B.; Matthies, S.; Philipsen, A. Mindfulness vs psychoeducation in adult ADHD: A randomized controlled trial. Eur. Arch. Psychiatry Clin. Neurosci. 2018, 268, 321-335. [CrossRef]

110. Boettcher, J.; Åström, V.; Påhlsson, D.; Schenström, O.; Andersson, G.; Carlbring, P. Internet-based mindfulness treatment for anxiety disorders: A randomized controlled trial. Behav. Ther. 2014, 45, 241-253. [CrossRef]

111. Goldin, P.; Ziv, M.; Jazaieri, H.; Hahn, K.; Gross, J.J. MBSR vs aerobic exercise in social anxiety: fMRI of emotion regulation of negative self-beliefs. Soc. Cogn. Affect. Neurosci. 2013, 8, 65-72. [CrossRef]

112. Koszycki, D.; Benger, M.; Shlik, J.; Bradwejn, J. Randomized trial of a meditation-based stress reduction program and cognitive behavior therapy in generalized social anxiety disorder. Behav. Res. Ther. 2007, 45, 2518-2526. [CrossRef]

113. Huberty, J.L.; Green, J.; Puzia, M.E.; Larkey, L.; Laird, B.; Vranceanu, A.-M.; Vlisides-Henry, R.; Irwin, M.R. Testing a mindfulness meditation mobile app for the treatment of sleep-related symptoms in adults with sleep disturbance: A randomized controlled trial. PLOS ONE 2021, 16, e0244717. [CrossRef]

114. Black, D.S.; O'Reilly, G.A.; Olmstead, R.; Breen, E.C.; Irwin, M.R. Mindfulness meditation and improvement in sleep quality and daytime impairment among older adults with sleep disturbances: A randomized clinical trial. JAMA Intern. Med. 2015, 175, 494-501. [CrossRef]

115. Ong, J.C.; Manber, R.; Segal, Z.; Xia, Y.; Shapiro, S.; Wyatt, J.K. A randomized controlled trial of mindfulness meditation for chronic insomnia. Sleep 2014, 37, 1553-1563. [CrossRef]

116. Zgierska, A.E.; Burzinski, C.A.; Mundt, M.P.; McClintock, A.S.; Cox, J.; Coe, C.L.; Miller, M.M.; Fleming, M.F. Mindfulness-based relapse prevention for alcohol dependence: Findings from a randomized controlled trial. J. Subst. Abus. Treat. 2019, 100, 8-17. [CrossRef]

117. Hsu, S.H.; Collins, S.E.; Marlatt, G.A. Examining psychometric properties of distress tolerance and its moderation of mindfulnessbased relapse prevention effects on alcohol and other drug use outcomes. Addict. Behav. 2013, 38, 1852-1858. [CrossRef]

118. Loizzo, J. Meditation research, past, present, and future: Perspectives from the Nalanda contemplative science tradition. Ann. N. Y. Acad. Sci. 2014, 1307, 43. [CrossRef] [PubMed]

119. Barnes, P.M.; Powell-Griner, E.; McFann, K.; Nahin, R.L. Complementary and Alternative Medicine Use among Adults: United States, 2002. In Seminars in Integrative Medicine; Elsevier: Amsterdam, The Netherlands, 2004; pp. 54-71.

120. Upchurch, D.M.; Johnson, P.J. Gender differences in prevalence, patterns, purposes, and perceived benefits of meditation practices in the United States. J. Women's Health 2019, 28, 135-142. [CrossRef] [PubMed]

121. Reyes-Gibby, C.C.; Aday, L.A.; Anderson, K.O.; Mendoza, T.R.; Cleeland, C.S. Pain, depression, and fatigue in communitydwelling adults with and without a history of cancer. J. Pain Symptom Manag. 2006, 32, 118-128. [CrossRef] [PubMed]

122. Kwekkeboom, K.L.; Cherwin, C.H.; Lee, J.W.; Wanta, B. Mind-body treatments for the pain-fatigue-sleep disturbance symptom cluster in persons with cancer. J. Pain Symptom Manag. 2010, 39, 126-138. [CrossRef] 
123. Shapiro, D.H.; Giber, D. Meditation and psychotherapeutic effects: Self-regulation strategy and altered state of consciousness. Arch. Gen. Psychiatry 1978, 35, 294-302. [CrossRef]

124. Wang, J.; Wu, X.; Lai, W.; Long, E.; Zhang, X.; Li, W.; Zhu, Y.; Chen, C.; Zhong, X.; Liu, Z. Prevalence of depression and depressive symptoms among outpatients: A systematic review and meta-analysis. BMJ Open 2017, 7, e017173. [CrossRef]

125. Gullich, I.; Ramos, A.B.; Zan, T.R.A.; Scherer, C.; Mendoza-Sassi, R.A. Prevalence of anxiety in patients admitted to a university hospital in southern Brazil and associated factors. Rev. Bras. Epidemiol. 2013, 16, 644-657. [CrossRef]

126. Kasala, E.R.; Bodduluru, L.N.; Maneti, Y.; Thipparaboina, R. Effect of meditation on neurophysiological changes in stress mediated depression. Complement. Ther. Clin. Pract. 2014, 20, 74-80. [CrossRef] [PubMed]

127. Finsterer, J.; Mahjoub, S.Z. Fatigue in healthy and diseased individuals. Am. J. Hosp. Palliat. Med. 2014, 31, 562-575. [CrossRef]

128. Ravindra, P.; Kutty, B.M. Functional importance of sleep: An overview. Indian J. Sleep Med. 2012, 7, 42-44.

129. Tang, Y.-Y.; Hölzel, B.K.; Posner, M.I. The neuroscience of mindfulness meditation. Nat. Rev. Neurosci. 2015, 16, $213-225$. [CrossRef] [PubMed]

130. Querstret, D.; Morison, L.; Dickinson, S.; Cropley, M.; John, M. Mindfulness-based stress reduction and mindfulness-based cognitive therapy for psychological health and well-being in nonclinical samples: A systematic review and meta-analysis. Int. J. Stress Manag. 2020, 27, 394-411. [CrossRef]

131. Della Valle, E.; Palermi, S.; Aloe, I.; Marcantonio, R.; Spera, R.; Montagnani, S.; Sirico, F. Effectiveness of Workplace Yoga Interventions to Reduce Perceived Stress in Employees: A Systematic Review and Meta-Analysis. J. Funct. Morphol. Kinesiol. 2020, 5, 33. [CrossRef]

132. Selye, H. Stress in Health and Disease; Butterworth-Heinemann: Oxford, UK, 2013.

133. Huebner, J.; Prott, F.J.; Micke, O.; Muecke, R.; Senf, B.; Dennert, G.; Muenstedt, K. Online survey of cancer patients on complementary and alternative medicine. Oncol. Res. Treat. 2014, 37, 304-308. [CrossRef]

134. Davidson, R.J.; Kaszniak, A.W. Conceptual and methodological issues in research on mindfulness and meditation. Am. Psychol. 2015, 70, 581. [CrossRef]

135. Kessels, E.; Husson, O.; Van der Feltz-Cornelis, C.M. The effect of exercise on cancer-related fatigue in cancer survivors: A systematic review and meta-analysis. Neuropsychiatr. Dis. Treat. 2018, 14, 479. [CrossRef]

136. Estévez-López, F.; Maestre-Cascales, C.; Russell, D.; Álvarez-Gallardo, I.C.; Rodriguez-Ayllon, M.; Hughes, C.M.; Davison, G.W.; Sañudo, B.; McVeigh, J.G. Effectiveness of exercise on fatigue and sleep quality in fibromyalgia: A systematic review and meta-analysis of randomized trials. Arch. Phys. Med. Rehabil. 2021, 102, 752-761. [CrossRef] [PubMed]

137. Razazian, N.; Kazeminia, M.; Moayedi, H.; Daneshkhah, A.; Shohaimi, S.; Mohammadi, M.; Jalali, R.; Salari, N. The impact of physical exercise on the fatigue symptoms in patients with multiple sclerosis: A systematic review and meta-analysis. $B M C$ Neurol. 2020, 20, 93. [CrossRef]

138. Niemeijer, A.; Lund, H.; Stafne, S.N.; Ipsen, T.; Goldschmidt, C.L.; Jørgensen, C.T.; Juhl, C.B. Adverse events of exercise therapy in randomised controlled trials: A systematic review and meta-analysis. Br. J. Sports Med. 2020, 54, 1073-1080. [CrossRef] [PubMed]

139. Groenvold, M.; Petersen, M.A.; Idler, E.; Bjorner, J.B.; Fayers, P.M.; Mouridsen, H.T. Psychological distress and fatigue predicted recurrence and survival in primary breast cancer patients. Breast Cancer Res. Treat. 2007, 105, 209-219. [CrossRef] [PubMed] 